\title{
Geology of and climatic indicators in the Westphalian A New Glasgow formation, Nova Scotia, Canada: implications for the genesis of coal and of sandstone-hosted lead deposits
}

\author{
F.W. Chandler \\ Geological Survey of Canada, 601 Booth Street, Ottowa, Ontario K1A 0E8, Canada
}

Date Received January 20, 1998
Date Accepted April 24, 1998

By the Late Carboniferous, Late Paleozoic northward drift of the continent Laurentia had carried Nova Scotia from the southern dry climate belt into the equatorial rainy belt. Carboniferous amalgamation of Laurentia with the southern continent Gondwana enclosed the area within the new supercontinent Pangea, imposing a gradually drying seasonal tropical climate. Disagreement exists on whether the early Pennsylvanian climate of the Euramerican coal province was everwet or seasonal. Abundant paleopedological evidence, including calcrete-bearing vertisols, shows that during formation of Westphalian C to Stephanian coals in Nova Scotia, the climate was tropical and seasonal with a pronounced dry season, but interpretation of Westphalian A-B coal-bearing sequences lacks this form of evidence. Development of calcrete-bearing vertisols in alluvial fan deposits of the Westphalian A New Glasgow formation indicate that a tropical climate with a pronounced dry season was already in force by early Westphalian time.

During the dry season, the coal swamps of the early Westphalian Joggins and Springhill Mines formations were fed by groundwater from coeval alluvial fan deposits of the Polly Brook Formation at the basin margin. Sedimentological evidence indicates that, similarly, ground water flowed northward from the toe of the New Glasgow alluvial fan, but correlative palustrine sediments have not been found on land in the New Glasgow area. The possibility remains of an early Westphalian coalfield associated with the New Glasgow formation to the north under the Northumberland Strait and Gulf of St. Lawrence.

Formation of the Yava sandstone-hosted lead deposit in the fluvial Silver Mine Formation of Cape Breton Island, a stratigraphic equivalent of the Cumberland Basin coal swamps, indicates that such deposits can form in fluvial strata deposited under a tropical seasonal climate with a pronounced dry season.

À la fin du Carbonifère supérieur, le déplacement vers le nord du Paléozoīque supérieur du continent laurentien avait emporté la Nouvelle-Écosse de la ceinture climatique sèche du Sud à la ceinture des pluies équatoriales. La fusion carbonifère du continent laurentien avec le continent méridional du Gondwana avait inséré la région à l'intérieur du nouveau supercontinent de la Pangée, imposant un climat tropical saisonnier qui s'est graduellement asséché. Certains croient que le climat du Pennsylvanien précoce de la province houillère euraméricaine était continuellement humide tandis que d'autres croient qu'il l'était de façon saisonnière. De nombreux indices paléopédologiques, dont des vertisols calcrétifères, révèlent qu'au cours de la formation des charbons du Westphalien $\mathrm{C}$ au Stéphanien en Nouvelle-Écosse, le climat était tropical et saisonnier, avèc une saison sèche prononcée, mais l'interprétation des séquences carboniferes du Westphalien A-B ne fournit pas ce type d'indices. Le développement de vertisols calcrétifères dans les gîtes en cônes alluviaux de la Formation du Westphalien A.de New Glasgow signale que la région bénéficiait déjà d'un climat tropical comportant une saison sèche prononcée à l'étage du Westphalien inférieur.

Pendant la saison sèche, les marécages houillers des formations du Westphalien inférieur de Joggins et de Springhill Mines étaient alimentées par l'eau souterraine des gîtes en cônes alluviaux contemporains de la Formation de Polly Brook, à la limite du bassin. Des indices sédimentologiques révèlent que, similairement, l'eau souterraine s'est dirigée vers le nord depuis le front du cône alluvial de New Glasgow, mais on n'a pas trouvé de sédiments palustres corrélatifs sur le sol dans le secteur de New Glasgow. Il reste possible qu'un terrain houiller du Westphalien inférieur ait été associé à la Formation de New Glasgow au nord, sous le détroit de Northumberland et le golfe du Saint-Laurent.

La formation du gîte de plomb inclus dans du grès de Yava à l'intérieur de la Formation fluviatile de Silver Mine dans l'île du Cap-Breton, un équivalent stratigraphique des marécages houillers du bassin de Cumberland, révèle que ce genre de gîtes peut se former dans des strates fluviatiles en présence d'un climat tropical saisonnier comportant une saison sèche prononcée.

[Traduit par la rédaction]

\section{INTRODUCTION AND PREVIOUS WORK}

During the Carboniferous, the Canadian Appalachian region was attached to the southern margin of the northwarddrifting, equatorial continent, Laurentia. The southern continent Gondwana, overtaking from the south, collided with
Laurentia in the Carboniferous, placing the Canadian Appalachian region within the interior of the supercontinent Pangea (Scotese and McKerrow, 1990). By the late Carboniferous, the Appalachian orogen of the USA and Canada and parts of western Europe had reached near-equatorial latitudes and were the site of the Euramerican coal prov- 
ince, a major source of energy that fuelled the Industrial revolution (Calder and Gibling, 1994). The major phase of peat formation, mainly of Pennsylvanian age, commenced in the Namurian A and persisted to the end of the Stephanian (Calder and Gibling, 1994).

The Carboniferous climate in the coal province is interpreted to have changed from dry-seasonal in the Mississippian (Wright and Robinson, 1988; Wright, 1990; Vanstone, 1991; Fastovsky et al., 1993; Schenk et al., 1994; Caudill et al., 1996), while its component terranes were separate and in low southern latitudes, to equable and wet (McCabe and Schenk, 1982; Cecil, 1990; Cecil et al., 1985, 1994; Donaldson et al., 1985; Eble, 1985; Phillips and Peppers, 1984; Winston and Stanton, 1989) or possibly seasonal wet (Calder and Gibling, 1994) during early Westphalian time, as the newly assembled terranes entered equatorial latitudes. The mountain belt resulting from collision of Gondwana and Laurussia to form Pangea may have maintained a wet equatorial climate, temporarily counteracting the monsoonal climate expected from supercontinent assembly (Otto-Bliesner, 1993; Witzke, 1990). This strengthening monsoonal effect imposed an increasingly drier seasonal equatorial climate in the late Pennsylvanian (Robinson, 1973; Rowley et al., 1985; Crowley et al., 1989; Kutzbach and Gallimore, 1989; Winston and Stanton, 1989; Ziegler, 1989; Cecil, 1990; Witzke, 1990; Wright, 1990; Gibling and Rust, 1992; Parrish, 1993; Calder and Gibling, 1994), though some have presented evidence of late Westphalian wet phases (Garces et al., 1996; Phillips and Peppers, 1984).

In Nova Scotia (Fig. 1), economic coals are of late Westphalian A to early Westphalian B age in the Joggins Formation and the lower half of the Springhill Mines Formation of the Joggins-Springhill area (Ryan and Boehner, 1994), of Westphalian C-D age in the Stellarton Formation of the New Glasgow area (Dolby in Yeo et al., 1988; Naylor et al., 1989, 1992; Calder, 1994; Chandler et al., 1998), and of Westphalian C-Stephanian age in the Sydney Basin of Cape Breton Island (Gibling et al., 1992a). Good evidence from abundant calcic vertisols in Nova Scotian se-

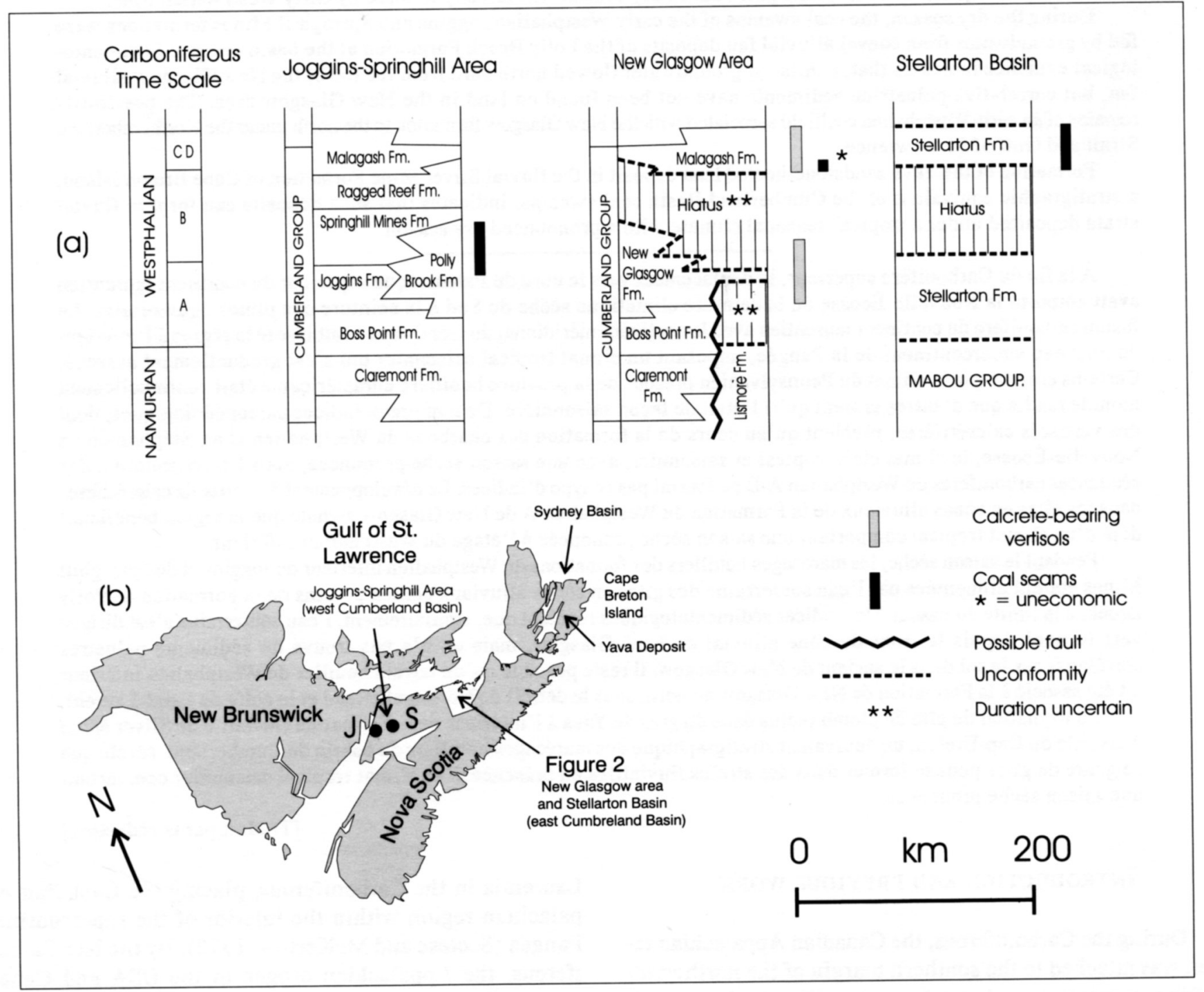

Fig. 1. (a) Stratigraphic correlation of Westphalian rocks of the New Glasgow area with those of the Joggins-Springhill area, modified from Ryan and Boehner (1994), with (b) location map. Data for age assignment of formations are from Dolby (1987, 1988), Johnson (1995), St. Peter (personal communication, 1997), G. Dolby (personal communication, 1996, 1998) and Chandler et al. (1998). 
quences (Gibling et al., 1993; Gibling and Bird, 1994; Gibling and Wightman, 1994; Chandler, 1994, 1997a) indicates that in Westphalian C-Stephanian time the climate of the Canadian Appalachian region was strongly seasonal, with a pronounced dry season. Thus the later coals of the Stellarton Basin and Cape Breton Island formed under strongly seasonal tropical local climates, a conclusion supporting the contention of Parrish (1993) that high water tables, rather than an everwet climate, are required to form coal deposits.

The New Glasgow formation (Fig. 2) is an early Westphalian, red alluvial fan deposit. It is lithologically similar to and broadly correlative with the Polly Brook Formation, an alluvial fan deposit interpreted as a groundwater source that fed the mires in which were formed the Joggins and Springhill coals of the western Cumberland Basin (Calder, 1994).

Owing to its very poor exposure, the New Glasgow formation is relatively unknown. A recent study (Chandler, 1997b) of exposures and of drill core from diamond drill hole P-58-86 (Figs. 2,3 ) revealed abundant evidence of vertisols bearing nodular calcrete, a paleopedological indicator of tropical to subtropical climates with a pronounced dry season (Dudal and Eswaran, 1988; Wright, 1990; Retallack, 1997). Also, the stratigraphic distribution of drab units and plant remains and of calcrete, both nodular-pedogenic and as a cement in conglomerate, provide an indication of the groundwater regime in the fan during deposition.

The purpose of this paper is to document more fully the synsedimentary paleoclimate and paleohydrology of the New Glasgow formation, features that relate to modelling of the genesis of early Westphalian coals and sandstone-hosted lead deposits in the Canadian Appalachians.

\section{The New Glasgow formation}

The New Glasgow Conglomerate (Dawson, 1845) was a member of the Pictou series of Dawson (in Bell, 1925) and later a formation (New Glasgow formation) within the Cumberland Group (Ryan et al., 1991). It featured in early discussions (Bell, 1925) on the geology of the Carboniferous coal measures of the Stellarton Basin immediately to the south (Fig. 2). The formation is restricted to the New Glasgow area of northern mainland Nova Scotia and has been deformed into a gently northeast-plunging $Z$-fold, the Scotsburn Anticline and the complementary Trenton Syncline (Webb, 1969). The north-striking limb of the Trenton Syncline forms the prominent Green Hill, and the east-striking limb forms Frasers Mountain, immediately east of New Glasgow (Chandler et al., 1998).

Thinning of the conglomerate eastward to Merigomish Harbour and westward to the River John, as well as northward, convinced Bell $(1925,1926,1940)$ that the unit had the shape of an alluvial fan, deposited by mountain streams flowing through the Stellarton Gap that lies between the Antigonish and Cobequid Highlands. Lithology and boulder size of clasts supported this interpretation (Bell, 1926). Fralick and Schenk (1981), also noting eastward-thinning of the conglomerate as well as eastward and northward reduction of clast size, suggested deposition in a "braided stream system". Like Webb (1969), they interpreted the formation as shed northeastward from an eroding lower Carboniferous source area during dextral strike-slip faulting related to continental collision, an event now thought of in terms of the assembly of Pangea. Gillis (1964), however, interpreted

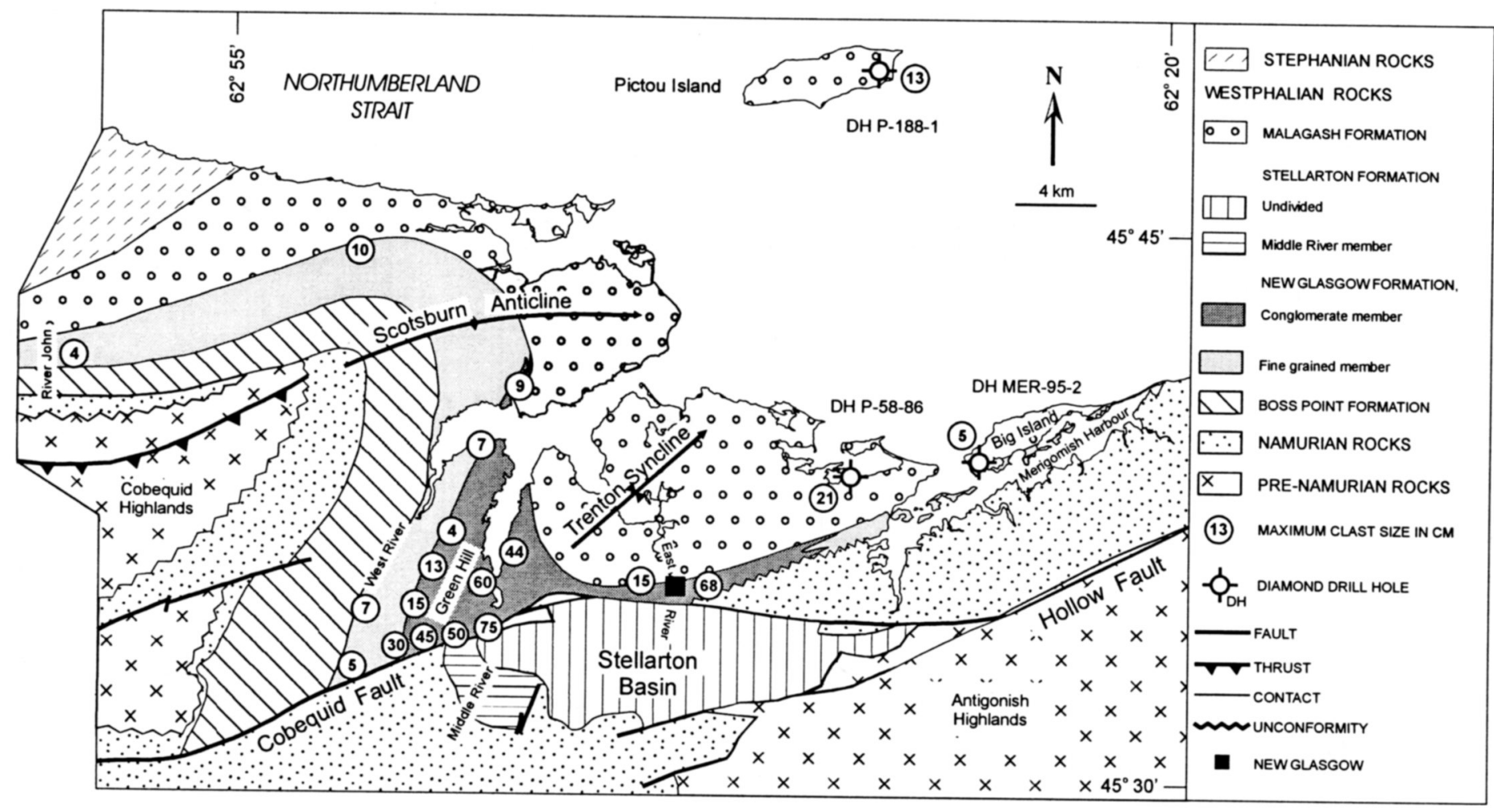

Fig. 2. Geological map of the New Glasgow formation and surrounding units, northern Nova Scotia, simplified from Chandler $e t$ al. (1998). 


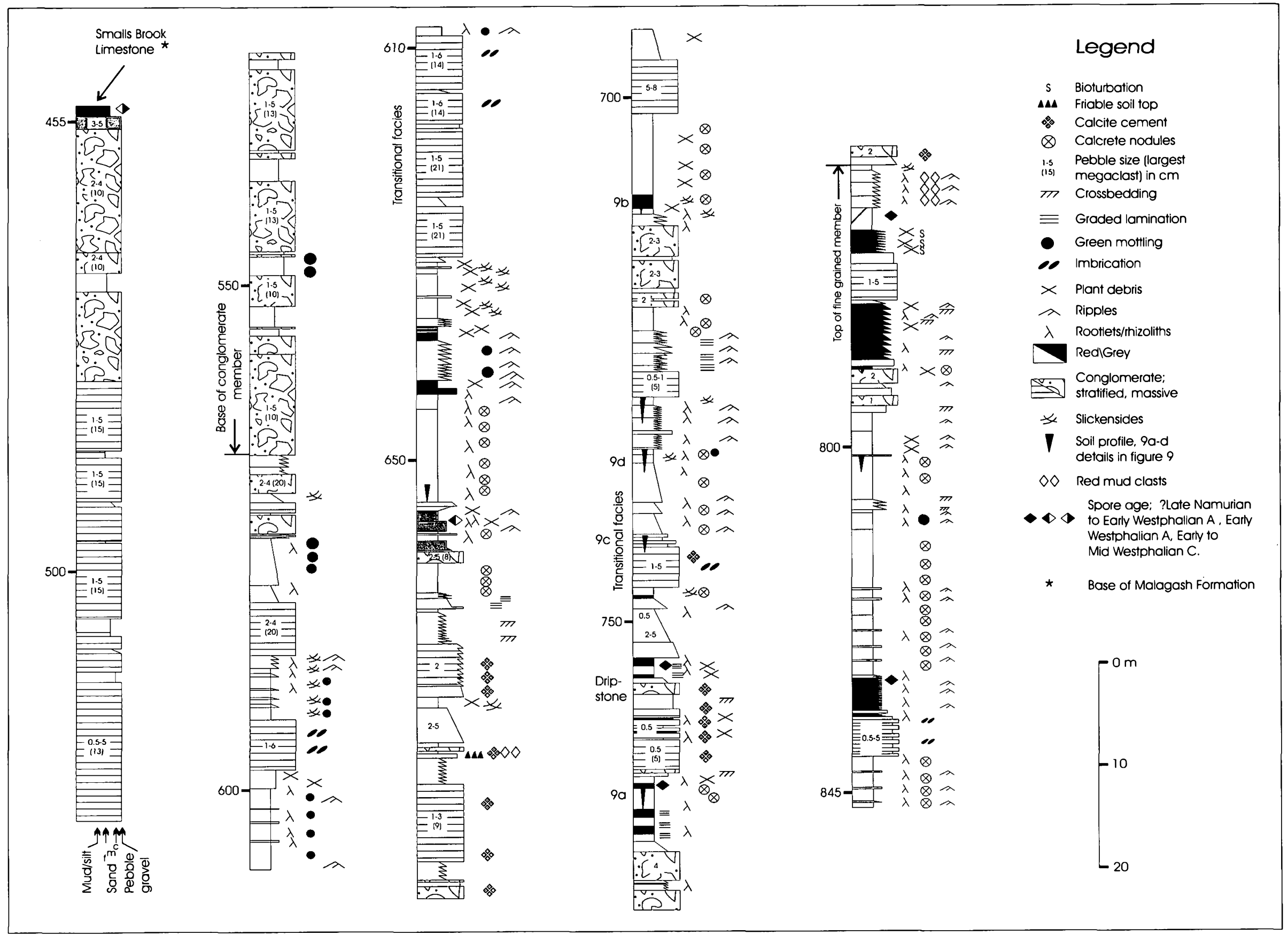

Fig. 3. Lithological log of drill core P-58-86 to show the conglomerate member and the underlying transitional facies to the fine-grained member. The Smalls Brook Limestone lies at the base of the Malagash Formation (cf. Fig. 2). 
the conglomerate as a fluvial "piedmont" deposit, fining south, and interpreted sandstone of the Middle River Formation, now the Middle River Member of the Stellarton Formation (Waldron et al., 1997; Chandler et al., 1998), as a southern correlative. However, this correlation is uncertain because of dextral strike-slip offset of 20 to $35 \mathrm{~km}$ on the CobequidHollow Fault (Yeo, 1985; Yeo and Gao, 1986) that separates the New Glasgow formation from the Stellarton Basin (Fig. 2).

Bell (1926) referred to, but did not interpret, a decrease in clast size in the New Glasgow formation, eastward to Merigomish Harbour and westward to River John. Cross-bedding in sandstone and shingling (imbrication) in the conglomerate suggested to him a source in the south or southeast. According to Gibling et al. (1992b), clast imbrication indicates northwestward flow for the conglomerate, but trough cross-bed measurements indicate northeastward to southeastward paleoflow for the underlying Middle River Formation that lies north of the Cobequid Fault, and is now interpreted as the fine-grained member of the New Glasgow formation (see below).

\section{Subdivision of the New Glasgow formation}

A fine-grained redbed unit underlying the New Glasgow Conglomerate was recognized as a separate stratigraphic unit and variously assigned to local formations such as the Lismore (Bell, 1926), Boss Point (Gillis, 1964), Middle River (Yeo, 1987) and Malagash (Ryan and Boehner, 1994). Field studies by Yeo (1987) and Chandler et al. (1998) have shown that the conglomerate and the fine-grained unit are spatially associated, interdigitating, local accumulations. Their diachronous relationship is illustrated on Figure 2. An intervening unit, $210 \mathrm{~m}$ thick, of interbedded coarse- and fine-grained clastic rocks could not be mapped as a separate unit, but was recognizable in drill core (Fig. 3). The fine-grained unit contains thin pebble conglomerate horizons with pebbles lithologically like those of the conglomerate. These observations prompted gathering of the two mappable units as the conglomerate member and the fine-grained member of the informally defined New Glasgow formation (Chandler, 1994).

Diamond drill hole P-58-86, located $9 \mathrm{~km}$ northeast of New Glasgow (Fig. 2), penetrated $455 \mathrm{~m}$ of the Malagash Formation (Ryan et al., 1991) and the underlying upper $391 \mathrm{~m}$ of the New Glasgow formation. The latter (Fig. 3) consists of the entire conglomerate member, defined here from drill core as consisting of more than $50 \%$ conglomerate beds and lying between depths of 455 and $565 \mathrm{~m}$. Between $565 \mathrm{~m}$ and $775 \mathrm{~m}$ are subequal amounts of interbedded conglomerate, sandstone and mudstone to siltstone, a unit that is not mappable and here designated as a transitional facies. This combined thickness of $320 \mathrm{~m}$ is much less than the estimate of $927 \mathrm{~m}$ by Bell (1940, p. 20) for the thickness of the conglomerate, from bore hole data closer to the fan head.

Below the transitional facies, to the bottom of the hole at a depth of $845 \mathrm{~m}$, is the upper $70 \mathrm{~m}$ of the fine-grained member. Field measurement west of Green Hill shows this member to be $600 \mathrm{~m}$ thick. The fine-grained member is more extensive than previously shown by Yeo (1987) and Ryan and Boehner (1990). Proximally it underlies the New Glasgow Conglomerate, and distally the Westphalian C-D Malagash Formation (Fig. 2). From the $600 \mathrm{~m}$ thickness west of Green Hill, the finegrained member thins northwest, on River John and eastward in Merigomish Harbour, to about $300 \mathrm{~m}$. The thickness in Merigomish Harbour is suspect due to the possibility of strikeparallel faulting (Chandler et al., 1998); however, no evidence of faulting was seen in core MER-95-2, drilled by the Nova Scotia Department of Natural Resources at the east end of Big Island.

\section{GEOMETRY AND PALEOCURRENTS OF THE NEW GLasgow fORMation}

The size of the largest clast in exposures of the New Glasgow formation, with data added from drill core, shows a semicircular northward decrease (Fig. 2). This observation supports earlier interpretations of the conglomerate as an alluvial fan. The boulder size of many clasts in the conglomerate member immediately north of the Cobequid Fault suggests that the fan head was located near the fault and that the fan formed in response to elevation on the south side of the fault.

The conglomerate member was intersected in drill hole DH P-188-1 on Pictou Island, $28 \mathrm{~km}$ to the northeast of the fault and conglomerate beds are present in the fine-grained member on the River John. Assuming conservatively that the fan was semicircular in plan, although clast size distribution suggests elongation to the north-northeast, it had an area of at least $980 \mathrm{~km}^{2}$, and at least half the radius of the Kosi megafan, a very large present-day fan (Singh et al., 1993).

The first systematically collected maximum clast size data (Fig. 2) support earlier suggestions of north-northeastward transport for the conglomerate member. Similarly, six pebble imbrication measurements from the conglomerate member, and one measurement from the fine-grained member at $005^{\circ}$ (Fig. $4 a)$, yield a vector mean of $354^{\circ}$, in agreement with previous suggestions of northward transport (Gibling et al., 1992b). At the site of drill hole P-58-86, at least $9 \mathrm{~km}$ distally from the inferred head of the fan, pebble size has diminished from boulder size to the 1 to $5 \mathrm{~cm}$ range, apart from rare larger clasts. No obvious upward- or downward-fining is apparent through the conglomerate member.

Twenty-two current lineations from the fine-grained member have a bimodal pattern, with a vector mean of $039^{\circ}$ (Fig. 4b), rather more northerly than the eastward flow suggested by Gibling et al. (1992b) for the lower member (their Middle River Formation).

\section{Age and CORRelation OF THE NEW Glasgow FORMATION}

Regional mapping (Ryan and Boehner, 1990; Ryan et al., 1990a,b,c; Chandler et al., 1998) demonstrates the continuity of the Boss Point Formation between the Joggins, Springhill and the New Glasgow areas (Fig. 1). The Joggins, Polly Brook 


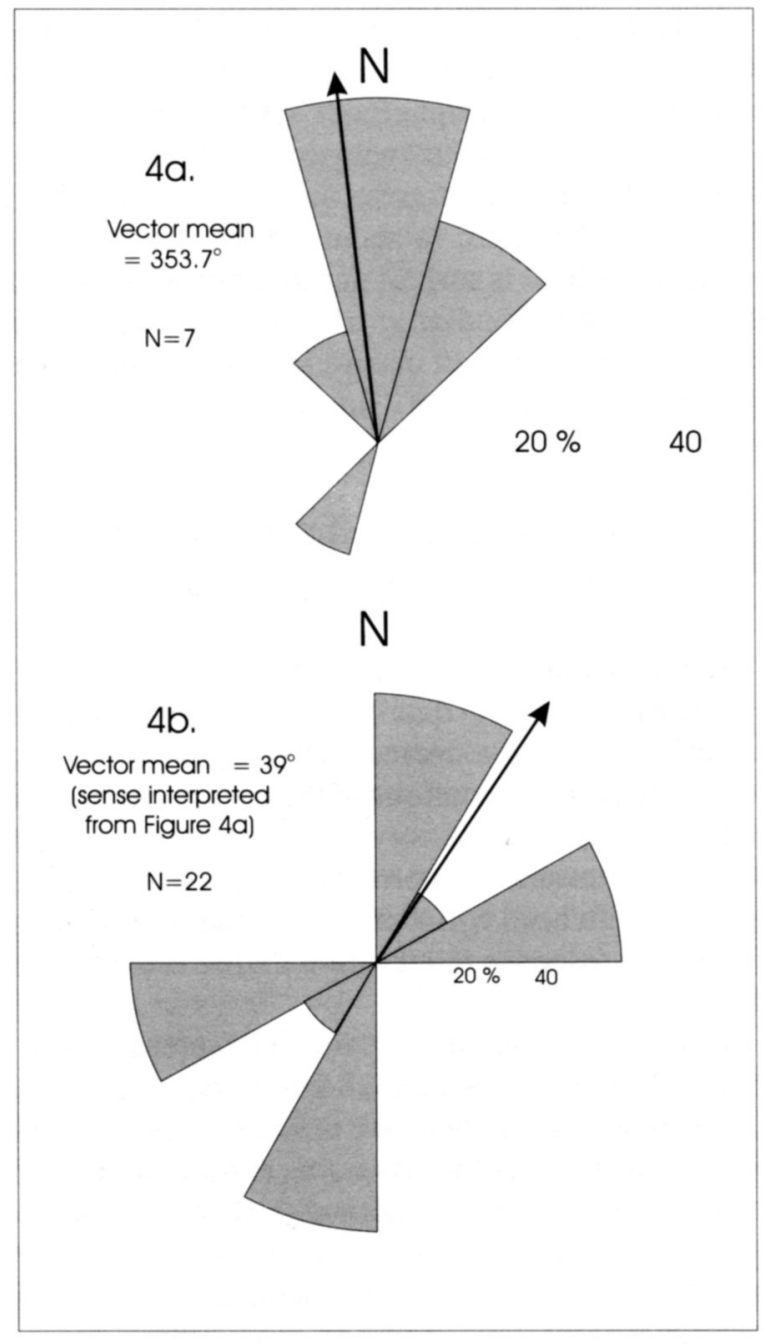

Fig. 4. Sediment transport directions of the New Glasgow formation. (a) Pebble imbrication in the conglomerate member. (b) Current lineations from the fine-grained member.

and New Glasgow formations overlie the Boss Point Formation in these areas, respectively, generally conformably (Calder, 1985; Ryan et al., 1991; Chandler et al., 1998) (Fig. 2). However, reports of an unconformity between the Boss Point and Polly Brook formations (see Ryan and Boehner, 1994) should be mentioned. Like the Polly Brook Formation (Ryan and Boehner, 1994), the New Glasgow formation consists of alluvial fan sediments derived from Highlands to the south. As noted above, the New Glasgow formation is mapped as consisting of a lower, distal, fine-grained member and a proximally overlying conglomeratic member (Chandler et al., 1998). The fine-grained Joggins Formation was interpreted by Calder (1994) as correlative with the lower part of the conglomeratic Polly Brook Formation or by Ryan and Boehner (1994) as a distal facies of it. These lithostratigraphic and sedimentological similarities suggest time equivalence of the New Glasgow formation with the Joggins and Polly Brook formations.

Use of palynological chronostratigraphy broadly supports these lithostratigraphic correlations. The Boss Point Formation ranges from latest Namurian $\mathrm{C}$ to late Westphalian $A$ in age in southeastern New Brunswick (Johnson, 1995;
C. St. Peter, personal communication, 1997), but at Joggins spore ages were reported as ranging from early to ?middle Westphalian A, with inherited? Namurian-early Westphalian species up to mid- to ?late Westphalian A (Dolby, 1987, 1988). At New Glasgow four samples in the upper part of the Boss Point Formation (Chandler et al., 1998) are of ?late Namurian to early Westphalian A age (G. Dolby, personal communication, 1994). Dolby (personal communication, 1998) now believes that the Boss Point Formation ranges in age in Nova Scotia from late Namurian C into early Westphalian A.

Spore ages for the Joggins Formation were reported in Ryan and Boehner (1994) as ?mid-Late Westphalian A to Westphalian A-B undifferentiated. G. Dolby (personal communication, 1998) has now placed the entire Joggins Formation with the Westphalian A, with the lower three quarters of the formation no younger than early Westphalian $A$ in age. The Polly Brook Formation is Westphalian A to middle Westphalian B in age (Dolby, 1988). The upper part of the distal member of the New Glasgow formation in drill hole P$58-86$, where overlain by over $200 \mathrm{~m}$ of the conglomeratic upper part of the formation, is of late Namurian to early Westphalian A age (G. Dolby, personal communication, 1996) (Fig. 3). The New Glasgow formation is overlain without angular discordance by drab fluvial sandstone and red floodplain deposits of the early Westphalian C to Westphalian D Malagash Formation (Chandler et al., 1998). Therefore the upper part of the New Glasgow formation could extend well into Westphalian B in age.

Dolby $(1987,1988)$ cautioned that his age interpretations for the Joggins section were "somewhat tentative" and "highly confusing", citing also a lack of marker species and reworking of stratigraphically important species into younger formations. However, his more recent work (G. Dolby, personal communication, 1998) supports the above lithostratigraphic correlations.

\section{Lithofacies of the New Glasgow formation}

\section{Conglomerate member}

The conglomerate member is entirely red and although it is resistant to erosion, only two stratigraphic sections of significant thickness were found. One section, $29.25 \mathrm{~m}$ thick, is the type section of Bell (1926) on the bank of the East River of Pictou at the bridge in the centre of New Glasgow (Fig. 5a). A second section, on Green Hill, preserves $2.9 \mathrm{~m}$ of section (Fig. 5b). A third incomplete section, at least 50 $\mathrm{m}$ thick, lies in the bed of the Middle River of Pictou where it is crossed by the Trans-Canada Highway, and is exposed only when the river is low after a very dry summer.

Boulder to pebble conglomerate comprises $94 \%$ of the first section (Fig. 5a), of which $49 \%$ is massive disorganized conglomerate (Fig. 6a), $45 \%$ is stratified conglomerate, and $6 \%$ is imbricate conglomerate. The second section (Fig. 5b) contains $72 \%$ of stratified conglomerate and $14 \%$ of imbricate conglomerate. In fifteen of the better, small, scattered exposures of the conglomerate member eight are stratified, five are composed of imbricate clasts, two are massive, one 


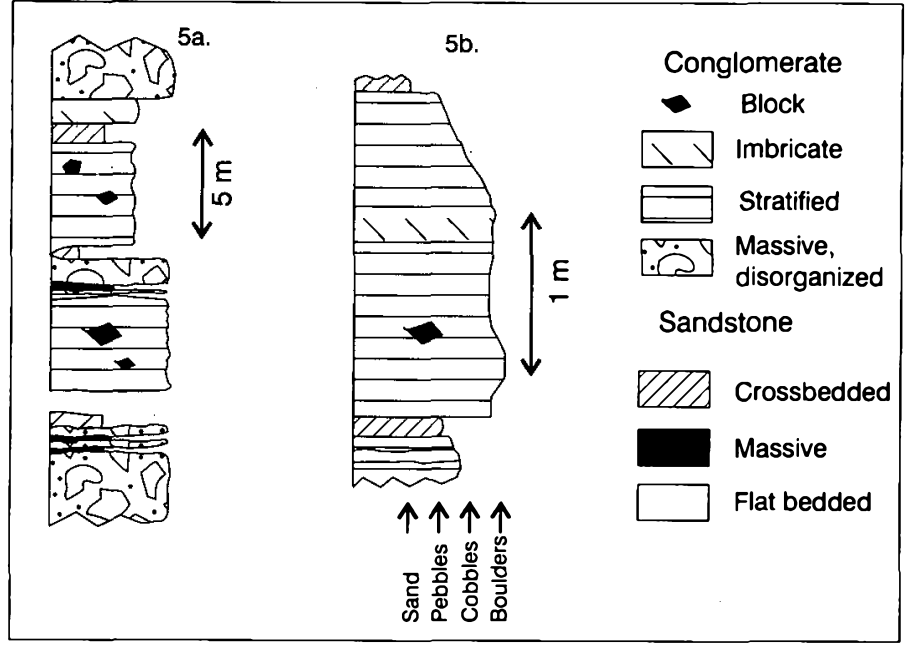

Fig. 5. Stratigraphic sections, measured from the conglomerate member, New Glasgow formation. (a) From New Glasgow. (b) At site of $60 \mathrm{~cm}$ clast size measurement, Green Hill (Fig. 1).

is normally graded and one is cross-bedded. At five of these locations the conglomerate is cemented by white sparry calcite.

In drill hole P-58-86, conglomerate appears poorly sorted and clast supported. Mud-rich matrix-supported conglomerate is very rare. Conglomerate in the drill core (Fig. 3) is divisible into stratified (53\%) and massive $(47 \%)$. The massive conglomerate lacks imbrication and three beds are cemented by white sparitic calcite. The stratified conglomerate is bedded on a 1 to $30 \mathrm{~cm}$ scale, contains sparse examples of imbrication ( 7 examples) and of sparitic calcite cement (10 examples).

Interbedded sandstone (Fig. 6a) comprised $6 \%$ of the section at New Glasgow (Fig. 5a) and $17 \%$ of the conglomerate member in drill core P-58-86. In exposure, sand beds are commonly lenticular, up to $4 \mathrm{~m}$ across and less than $40 \mathrm{~cm}$ thick. They are commonly cross-bedded or flat bedded. One bed contained plant remains.

\section{Fine-grained member}

In general, the dominantly red, fine-grained member consists of shale, siltstone, and medium-grained sandstone, with minor sandstone and carbonate pebble to cobble conglomerate, arranged in many cases into upward-fining cycles typically usually $<2 \mathrm{~m}$ thick. (Fig. 3). Sandstone beds are micaceous with flat-bedded or cross-bedded lower parts and rippled tops. They contain red and rare green mud chips, green or carbonaceous root and stem traces and clay-coated oxidised plant fragments. The siltstones and mudstones contain mud cracks. Bleached patches, in situ root and stem traces at a high angle to bedding, vertisol slickensides, calcrete nodules, rare rhizoliths and blocky fracture also occur, in many cases within distinct soil profiles. Root traces are generally less than $0.5 \mathrm{~cm}$ across and rarely traceable more than $30 \mathrm{~cm}$ vertically.

Isolated exposures of the fine-grained member aid identification of larger sedimentary structures. A $21.5 \mathrm{~m}$ stratigraphic
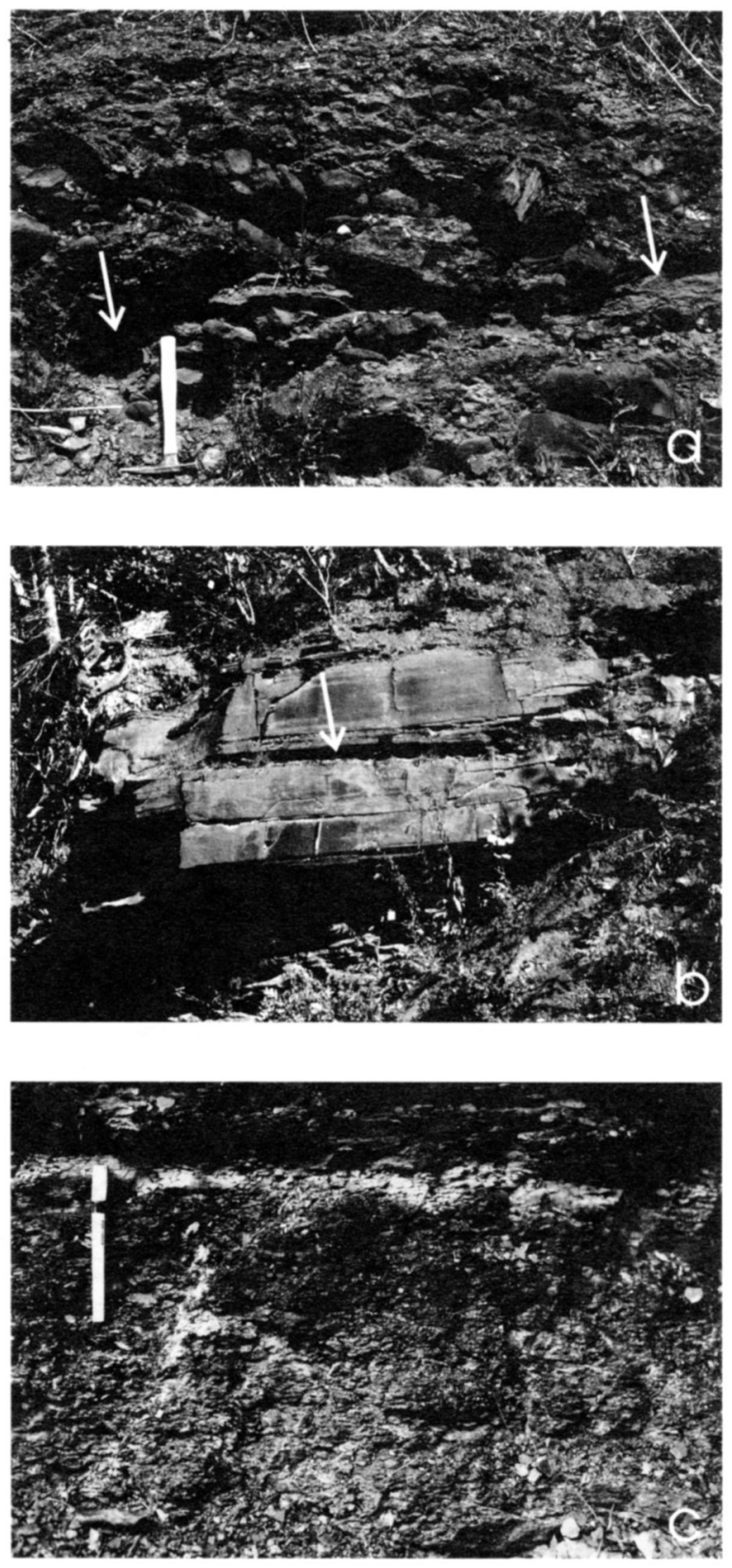

Fig. 6. Climate-influenced features of the New Glasgow formation. (a) Poorly sorted debris flow conglomerate, conglomerate member, interbedded $15 \mathrm{~cm}$ thick sand bed is arrowed. Hammer is $30 \mathrm{~cm}$ long. (b) Flat bedded, sandstone bed, $1.5 \mathrm{~m}$ thick, in fine-grained member with rippled interbed (arrowed). (c) Poorly developed soil profile in the fine-grained member, River John. Five $\mathrm{cm}$ thick irregular, green soil top is marked by top of $14 \mathrm{~cm}$ pen.

section on the River John (Fig. 7a) consists of subequal amounts of sandstone and rippled siltstone. Sand bodies at this locality are up to $4 \mathrm{~m}$ thick and many consist of upward-fining cycles, with medium-grained, flat bedded or cross-bedded sandstone overlain by finer-grained rippled sandstone. Lensoid shape of a number of cross-bedded sandstone bodies in this section suggests that confined stream flow origin is common. A $1.5 \mathrm{~m}$ thick sandstone body consisting of 30 to $60 \mathrm{~cm}$ thick sets of planar to low angle cross-beds, separated by 


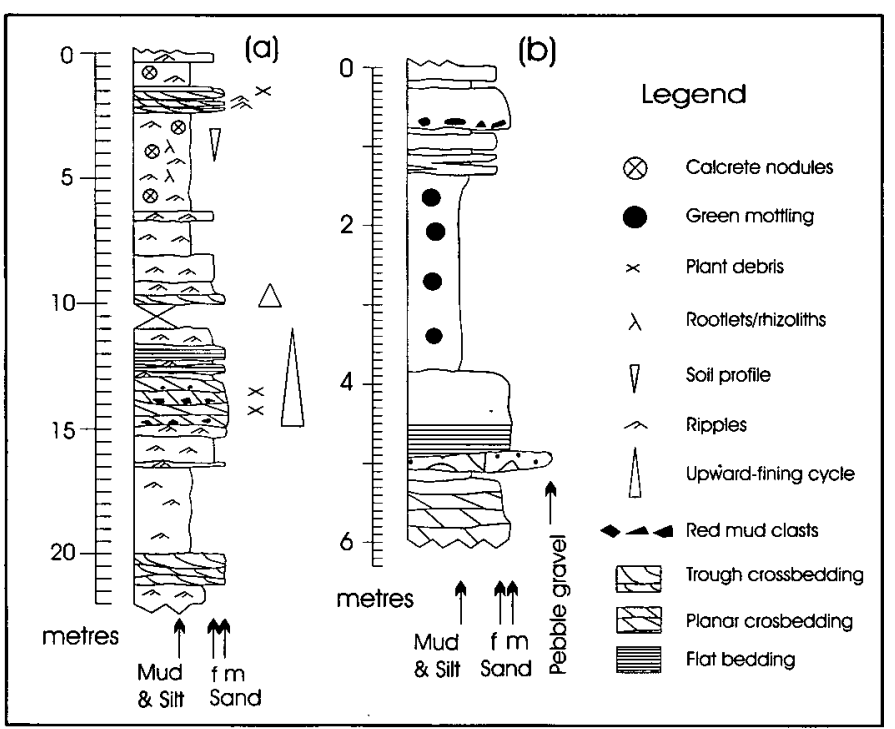

Fig. 7. Short stratigraphic sections of redbeds in the fine-grained member (a) near top of member, River John, and (b) near base of member, West River. For locations see Figure 2.

ca. 10 to $15 \mathrm{~cm}$ thick rippled units is illustrated in Figure $6 \mathrm{~b}$. Tapering branched roots are present in the sandstone.

The siltstone component of the section on the River John is rippled and contains scattered calcrete nodules and root traces. Immature soil profiles are present (e.g., Fig. 6c), consisting of a reduced (green) layer up to $5 \mathrm{~cm}$ thick, underlain by little-disturbed interbedded siltstone and mudstone into which downward-branching and tapering root traces penetrate for about $30 \mathrm{~cm}$. Fern impressions, leaf and plant stem fragments, equidimensional tetrapod footprints about $2 \mathrm{~cm}$ across, and a fallen tree stump $30 \mathrm{~cm}$ across were also noted in the siltstone component.

A $6.2 \mathrm{~m}$ thick stratigraphic section from the fine-grained member on the West River (Fig. 2) contains $45 \%$ of siltstone and mudstone units and one 15 to $25 \mathrm{~cm}$ thick, lenticular pebble conglomerate (Fig. 7b). Sedimentary structures are obscure. As in the River John section sandstone units are flat bedded or cross-bedded and mudstone is weakly root mottled.

A more complete record is present in drill core P-58-86 where siltstone and mudstone consist of about $30 \%$ of the transitional facies and more than $50 \%$ of the fine-grained member. The fine-grained member contains numerous sandstone-based upward-fining cycles $3.5 \mathrm{~m}$ or less in thickness. The siltstonemudstone upper parts of cycles contain bleached patches, root traces, mud cracks, vertisol slickensides, calcrete nodules (Fig. 8a), rare rhizoliths (Fig. 8b), and blocky fracture. Soils, discussed more fully below; are also visible. Rare orthoconglomerate occurs in beds up to $25 \mathrm{~cm}$ thick. They may consist of carbonate channel lags, reworked from pedogenic calcrete nodules or of sandstone clasts similar to those of the conglomerate member, with abundant red sandstone clasts up to $10 \mathrm{~cm}$ in size. As in the conglomerate member, conglomerate beds may show imbrication and may be cemented by white calcite.
Drab intervals are rare in exposures of the fine-grained member and are generally less that $1 \mathrm{~m}$ thick, rarely up to 4.5 $\mathrm{m}$. In drill core, they occur between 637 and $837 \mathrm{~m}$, i.e., below the upper third of the transitional facies. They generally consist of rippled, fine-grained grey and green sandstone with associated root traces and plant fragments. A few upwardfining cycles consist of green, plant fragment-rich sandstone grading up to red or green, graded silt-mud couplets.

One drab unit, between 655 and $657 \mathrm{~m}$, overlies red mudstone with calcrete nodules and consists in ascending order of $1 \mathrm{~m}$ of green rippled sandstone with root disturbance and organic debris flasers, $60 \mathrm{~cm}$ of black mudstone with horizontal plant fragments, and $30 \mathrm{~cm}$ of green rippled siltstone overlain by red siltstone.

A second drab unit, between $753.45 \mathrm{~m}$ and $755.35 \mathrm{~m}$, overlies four $10-\mathrm{cm}$ thick upward-fining cycles of medium- to finegrained red sandstone. It consists of beds of rippled, green silt to fine sand, 1 to $5 \mathrm{~cm}$ thick, alternating with plant fragment-bearing black mudstone laminae 0.5 to $1 \mathrm{~cm}$ thick. Root traces may penetrate several alternations. The unit is overlain by red pebble conglomerate.

A third drab unit, between 770.2 and $773.3 \mathrm{~m}$, overlies red siltstone that contains plant remains and is overlain by red mudstone with root traces. The unit consists of $3.1 \mathrm{~m}$ of graded, fine-grained, grey sand to mud units less than 2.5 $\mathrm{cm}$ thick. The mudstone in the lower half of the unit is red. A $30 \mathrm{~cm}$ deep root trace was noted in the middle of the unit.

A fourth drab unit, between 787 and $791.5 \mathrm{~m}$, overlies pink grit. It commences with $30 \mathrm{~cm}$ of black mudstone with plant fragments, overlain by a 2.2-m thick, grey, pedoturbated upward-fining unit of medium- to fine-grained, cross-bedded sandstone, then several 5 to $8 \mathrm{~cm}$ thick grey siltlblack mudstone cycles. The greylblack cycles are overlain by $2 \mathrm{~m}$ of interlaminated red and green mudstone. The unit is overlain by pebble conglomerate.

\section{Paleoclimate indicators}

\section{Paleosols}

No evidence of paleosols was seen in the conglomerate member. In contrast, abundant evidence of soil formation is present in the transitional facies and fine-grained member, in the form of mottled rooted zones, rhizoconcretions, nodular calcrete, bio- (pedo-) turbations and zones of low angle slickensides (Fig. 3). The slickensides occur in zones up to 20 to $30 \mathrm{~cm}$ thick of intersecting, multidirectional, horizontal to low-angle sets that divide the host mudstone into rhombohedral peds, commonly coated with red argillans (Retallack, 1990). Striations on the ped surfaces indicate that slip was in many cases along maximum dip directions of the slip surfaces.

Several soil profiles (Fig. 9) ranging up to $180 \mathrm{~cm}$ in thickness, are preserved in drill core P-58-86 (Fig. 3). The soil in Figure $9 \mathrm{a}$ is a thin $(42 \mathrm{~cm})$ grey mudstone in which roots have destroyed sedimentary structures. The roots taper down and one was traced $10 \mathrm{~cm}$ vertically. The grey colour suggests that the soil probably formed on wetter ground than the nu- 

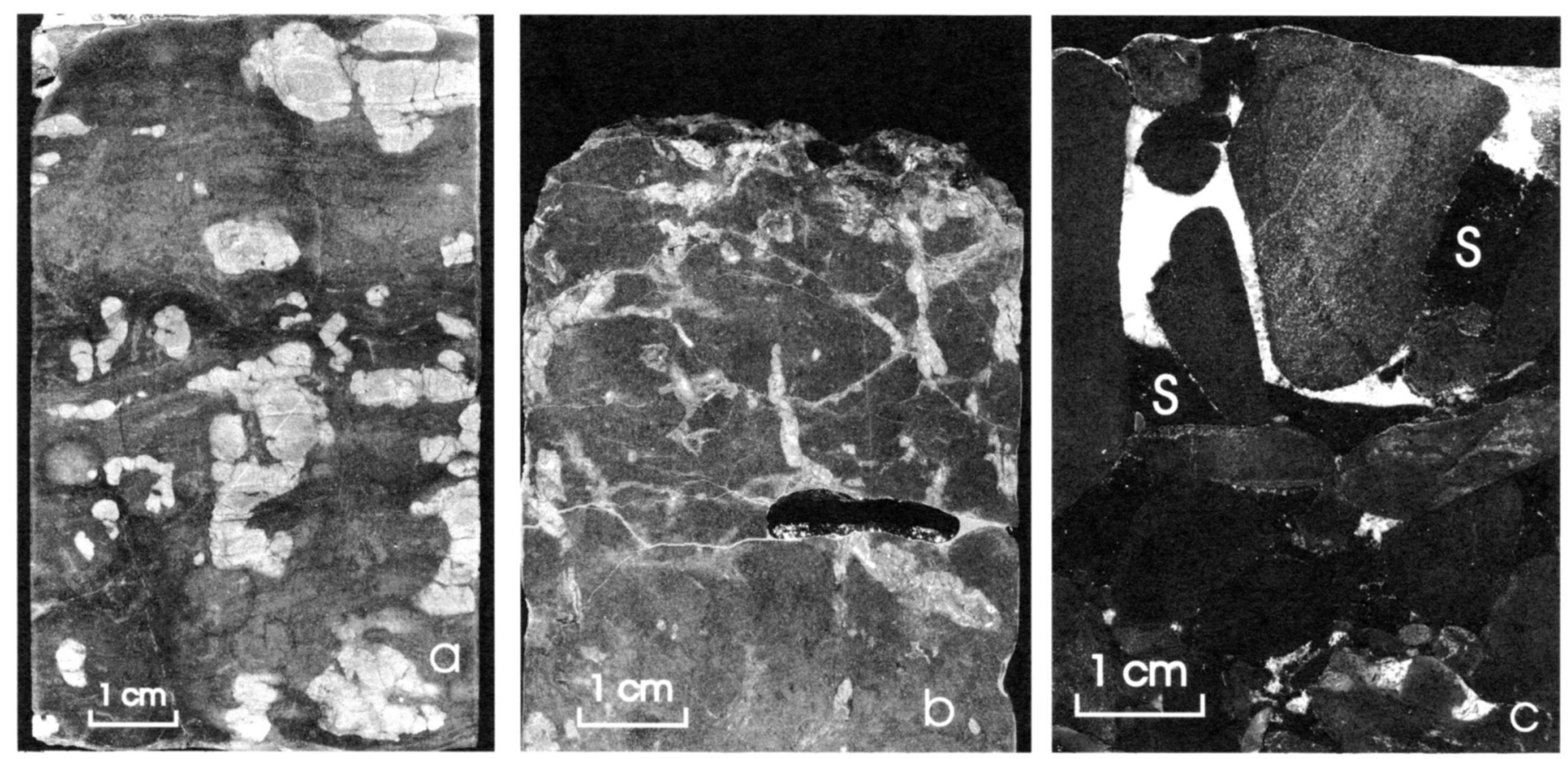

Fig. 8. Examples of climate-related calcite deposition, from drill core, drillhole P-58-86, New Glasgow formation. (a) Calcrete nodules (light) in red rippled siltstone, in transitional facies, at $653.9 \mathrm{~m}$ (Fig. 3). (b) Rhizoconcretions, some with dark carbon rich? cores, in fine-grained, rippled red sandstone, in transitional facies at $743.6 \mathrm{~m}$ (Fig. 3). Concretions occur immediately beneath soil profile $\mathrm{c}$ in Figure 8. Note lateral branching. (c) Clast-supported conglomerate in transitional facies, at $758.9 \mathrm{~m}$ (Fig. 3). Interclast voids are partially filled by downward-percolated fine red sand (s) and upper part of voids are cemented by later white sparitic calcite.

merous thin rooted zones present in mainly red mudstone in the formation (Fig. 3).

The $180 \mathrm{~cm}$ profile in Figure $9 \mathrm{~b}$ lies within red siltstone that contains calcrete nodules. It consists of dark grey massive mudstone, with pervasive scattered slickensides and calcrete nodules. Identification of root traces only from the base indicates vertic disturbance of most of the profile. The presence of calcrete nodules at the top of the profile would suggest arid conditions (Retallack, 1997) if it were not for the thickness of the soil and for evidence for relatively abundant rainfall in Westphalian A time (Chandler, 1997b), which would have caused calcrete formation to at least a depth of $30 \mathrm{~cm}$ (see profiles $9 \mathrm{c}$,d). This profile likely represents a mature soil which has lost its top by erosion.

The 63-cm thick paleosol shown in Figure 9c is overlain by massive, calcrete nodule-bearing red mudstone. The upper two parts of soil consist of $28 \mathrm{~cm}$ of red-brown mudstone overlying a $15-\mathrm{cm}$ thick grey mudstone, both of which are friable. The red-brown mudstone contains scattered, lowangle slickensides and the grey mudstone contains calcrete nodules and root traces up to $10 \mathrm{~cm}$ long. The lowest part of the soil consists of a $20-\mathrm{cm}$ thick cross-laminated red finegrained sandstone with abundant rhizoconcretions. Beneath the soil, rhizoconcretions are rare in similar sandstone.

The $125-\mathrm{cm}$ thick soil shown in Figure $9 \mathrm{~d}$ is overlain by red, rippled, fine-grained sandstone with rare rhizoconcretions. The soil top consists of $15 \mathrm{~cm}$ of red, friable massive mudstone. This zone is underlain by $23 \mathrm{~cm}$ of friable, massive, mottled mudstone with well-developed low- angle slickensides. Under this, $7 \mathrm{~cm}$ of massive, red mudstone contain abundant calcrete nodules, one $\mathrm{cm}$ in diameter. Beneath, white rootlet traces (rhizoconcretions) decrease in abundance through $80 \mathrm{~cm}$ of red rippled siltstone.

Like the profile shown in Figure 9b, these two last profiles probably represent vertisols, in the upper parts of which sedimentary structures and root traces have been destroyed during expansion and contraction of clays during alternating wet and dry seasons. One $5.62 \mathrm{~m}$ profile noted in drill core P-58-86 is not described here. It is composed of interbedded root, slickenside and calcrete nodule-bearing zones and is probably a set of superimposed soils.

\section{Calcrete}

Calcrete occurs in the New Glasgow formation in two forms, as white sparite cement in conglomerate and as nodular calcrete in fine-grained redbeds. Several exposures of conglomerate, within the conglomerate member, contain beds in which the red sand matrix is absent and the inter-pebble voids are cemented by white calcite, evidence of absence of matrix at the time of deposition. The calcite is common in beds of coarser $(1-3 \mathrm{~cm})$ stratified pebble orthoconglomerate, or of interbedded conglomerate and sandstone, ranging from 15 to $45 \mathrm{~cm}$ thick. Calcite cement was also noted in thin conglomerate beds near the base of the fine-grained member. In drill core, white sparitic calcite cement is restricted to the lower half of the transitional facies, a zone between 670 and $780.5 \mathrm{~m}$ in Figure 3. 
(a) Soit at $772.08 \mathrm{~m}$

(b) Soil at $709 \mathrm{~m}$
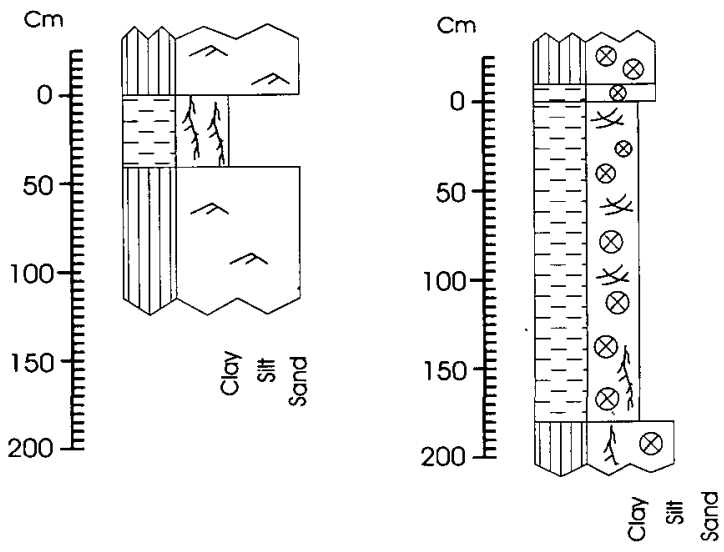

(c) Soil at $743.37 \mathrm{~m}$.

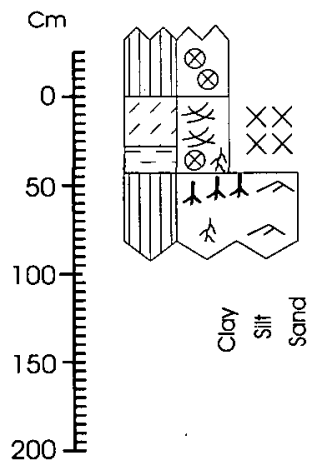

|IIIII Red
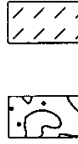

\section{Red-brown}

Red-green

mottling

Grey

Friable

Ripples

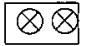

(d) Soll at $733.05 \mathrm{~m}$

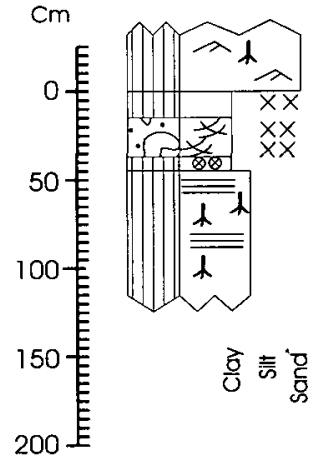

Root traces

Rhizoconcretions

Calcareous

nodules

Slickensides

Bedded

Fig. 9. Vertisol profiles from drill core P-58-86, New Glasgow formation. Stratigraphic positions of profiles are given in Figure 3. Top of profiles is at $0 \mathrm{~cm}$ on vertical scales. Profiles are discussed in the text.

In some conglomerate beds hematite-coated sand fills the lower part of calcite-cemented voids and coats the upper surface of pebbles (Fig. 8c). Some of this sand is interpreted as synsedimentary, the suspension load of the floods depositing the surrounding framework pebbles. The rest, with associated clays, may be post-depositional and could also have percolated down into the porous host conglomerate with

the water of succeeding floods (Selley, 1988). The clear white sparitic calcite that fills the upper part of the voids is unlikely to have crystallized from downward-percolating surface floodwater because it contains no fine sand grains or hematite. More probably, it was deposited by groundwater after the access of silt-bearing surface water had been sealed. In one case, at $759 \mathrm{~m}$, where void cementation was incomplete, the calcite was present as coatings of dripstone on the underside of clasts (Fig. 3), an example of phreatic deposition (Stalder, 1975; Funk, 1979).

Nodular calcrete was not found in outcrops of the conglomerate member, and is rare in exposures of the fine-grained member. In one example of the latter, a horizon of scattered nodules was found $1 \mathrm{~m}$ below the top of a soil horizon.

In drill core P-58-86, calcrete nodules (Calcrete stage 2 of Machette, 1985) are scattered throughout the lower part of the transitional facies, below $646 \mathrm{~m}$, i.e., below $24 \mathrm{~m}$ above the highest calcite-cemented conglomerate bed, as well as throughout the fine-grained member (Fig. 3). A strong association with mottled mudstone, plant remains, root traces, slickensides and reddening-down friable grey horizons (tops of soil profiles) indicates a pedogenic origin (Wright and Tucker, 1991).

\section{Discussion}

The fan shape, the coarseness and radial decrease in grain size, abundant disorganized conglomerate deposits, upstream termination as a boulder conglomerate at a fault system, (Nilsen, 1982; Galloway and Hobday, 1983; Orton, 1988; Miall, 1992, 1996; Reading, 1996), in this case at the Cobequid-Hollow Fault system and paleocurrents transverse to regional, orogenparallel, east-northeastward, fluvial drainage (Gibling et al., 1992b) all support an alluvial fan origin for the conglomerate member of the New Glasgow formation.

Distal thinning of the fine-grained member in the same directions as clast size decrease in the conglomerate member suggests that the member is part of the New Glasgow fan. Paleoflow of the fine-grained member to $\mathrm{N} 39^{\circ} \mathrm{E}$ is closer to the regional east-northeast late Pennsylvanian fluvial drainage direction of New Brunswick and Nova Scotia (Gibling et al., 1992b) than is that of the conglomerate member. This probably reflects interaction between the fan drainage pattern and the regional drainage pattern.

Stratified, clast-supported conglomerate, some of which is imbricate and matrix free and likely of stream flow origin (Maizels, 1989; Major, 1997), comprises at least half of the conglomerate in the conglomerate member (Figs. 3, 5). Massive and disorganized conglomerate, likely of debris-flow origin (Maizels, 1989; Major, 1997), which tends to form on the proximal reaches of alluvial fans (Nemec and Steel, 1984), makes up the remainder. Absence of matrix in some examples of massive conglomerate, near-absence of mud-supported massive conglomerate, and difficulty of recognizing sedimentary structures in conglomerate in drill core suggest that some stream flow conglomerate was mistakenly identified as massive conglomerate. Hence, stream flow was the most common depositional process for the conglomerate member. 
Crudely bedded conglomerate (facies Gm of Miall, 1992) with imbrication and interbedded lenses of sandstone (facies St and Sr of Miall, 1992) is common in the conglomerate member. Occurring in longitudinal bars, it is typical of ancient alluvial fan deposits (Nemec and Steel, 1984; Miall, 1992). Rarity of cross-bedded conglomerate, that is common in distal gravelly rivers (facies Gp, Gt of Miall, 1978), also supports interpretation of the New Glasgow formation as an alluvial fan deposit.

Two main climate-linked classes of alluvial fan have been recognized on the basis of dominant transport process; debris flow fans of arid or semiarid climate and fluvial or stream flow fans of humid climate (McGowen, 1979; Galloway and Hobday, 1983; Reading, 1996). According to Nilsen (1982) and Miall $(1992,1996)$, stream flow deposits are generally more characteristic of distal fan facies and humid fans, whereas debris flows are more characteristic of proximal fan facies and seasonal to irregular rainfall in arid climates.

However, the relationship between conglomerate type and aridity is not simple. Catastrophic floods that produce debris flows can occur in a range of climates and other factors such as steep slopes and a source that weathers to abundant clay favour debris flows (Miall, 1996). For example, debris flow-dominated alluvial fans are the most common type of Holocene alluvial fan in the forested central Appalachians where sedimentation is triggered by intense rainfall in a temperate humid environment and source rock lithology determines whether conglomerates are matrix- or clast- supported (Kochel, 1990). Similarly, mass flow deposits have been documented in humid mountainous regions of southwest Japan (Ono, 1990) and New Zealand (Pierson, 1980).

Stream flow gravels dominate some seasonal climate fans. The Yallahs Fan, Jamaica, which is subject to a seasonal tropical climate, with frequent intense rainfall from tropical storms every 4.75 years, is dominated by longitudinal fluvial bars composed of poorly stratified and sorted imbricate gravel (Wescott, 1990). The Kosi Fan, northern India, composed of fluvial gravels, is being deposited under a humid seasonal climate (Singh et al., 1993).

Gravel transport by a mixture of stream flow and debris flow also occurs under tropical monsoonal conditions. For example, modern fan/braid-delta deposits of Papua New Guinea are forming under a tropical monsoonal climate with a significant dry season. Stream flow and debris flow deposits are present, with the latter limited to proximal regions of the fans, where they comprise $30 \%$ of the total (Brierley et al., 1993). Some Stephanian A and B alluvial fan sequences of northern Spain contain thickly bedded, massive, unstratified debris flow orthoconglomerate with a red sandstone matrix, interbedded with stratified conglomerate and cross-bedded sandstone. Using paleomagnetic data, they were interpreted as mid-fan lobe deposits deposited in the tropics (Heward, 1978) and resemble the transitional facies of the New Glasgow formation.

The sedimentology of the fans described above shows that abundant debris flows form on fans with irregular rainfall in a range of climates. The Spanish fans are of particular interest here because they are broadly coeval with the New Glas- gow formation. Another point in common is that the Spanish fans were deposited in a probably similar climatic regime about $2000 \mathrm{~km}$ east-southeast of the New Glasgow formation in the Appalachian-Variscan collision orogen within Pangea (Ziegler, 1989). The mid-fan conglomerate of the Spanish fans is of stream flow and debris flow origin. Sporadic reddening of the conglomerate and listric surfaces in mid- and distal-fan fine-grained deposits, an indicator of vertisols, suggest a seasonal tropical climate. Presence of coals and abundant well-preserved plants including upright tree trunks (Heward, 1978) indicate forest development and a reasonably high water table on the mid-fan.

Because about half of the conglomerate in the conglomerate member of the New Glasgow fan is of stream flow type, there was significant local rainfall. Presence of pedogenic calcrete with numerous vertisols in the fan sediments attests to a tropical climate with a pronounced dry season, drier than that for the Spanish fans. Redness, calcite cement, and absence of plant remains indicate that the gravels of the conglomerate member were not vegetated and that the water table was low during the dry season. Drab facies and abundant evidence of rooted vegetation (Fig. 3) indicates periodically high water tables and local lacustrine and swampy conditions during deposition of the lower member, or distal facies, a relationship examined below.

The water table beneath the proximal parts of arid climate alluvial fans may be many hundreds of feet deep (1 foot $=0.305 \mathrm{~m}$ ) (Hunt, 1975). Likewise, wet alluvial fans, with a mud-poor framework, are highly transmissive aquifers (Galloway and Hobday, 1983; Ollier and Pain, 1996, p. 63). Distal areas of alluvial fans, where topographic and hydraulic gradients decrease markedly, are zones of shallow, meteoric ground water discharge (Galloway and Hobday, 1983). In both arid-semiarid and humid-zone settings wetlands commonly occur in the alluvial apron of alluvial fans (Galloway and Hobday, 1983; Flores, 1986) to the extent of supporting coal swamps in the face of unfavourable seasonality in the seasonal tropics (Calder, 1994).

Carbonate cement is an indicator of the groundwater regime within alluvial fans. It is common in Precambrian to present day alluvial fan deposits (Lattman, 1973; Nilsen, 1982; Kalliokoski, 1986), but has been little studied (Nilsen, 1982). It can form as groundwater calcrete, from carbonate-rich mobile groundwater, that has been concentrated during down-dip flow within the fan. The cement is precipitated mainly in the capillary fringe (vadose zone) directly above laterally moving subsurface groundwater, but can also be precipitated below the water table (phreatic zone). It occurs best near the surface where degassing and evapotranspiration are facilitated (Wright and Tucker, 1991). The cement occurs in arid (Abrams and Chadwick, 1994), semiarid, and seasonal tropical (Stanistreet and McCarthy, 1993) fans.

The calcite cement in the conglomerate of the New Glasgow fan is interpreted as groundwater calcrete and is classified as nearly all of stage 3 of Machette (1985), i.e., completely cemented. One Stage 1 occurrence of dripstone (Fig. 3) is evidence of limited vadose deposition. It formed where permeability was high, as in coarser clast-supported beds (see 
Kalliokoski, 1986). Sparitic texture and absence of evidence of associated roots suggest that it is not pedogenic.

Pervasive oxidation of the proximal conglomerate member and presence of calcite cement dominantly in conglomerate beds of the transitional facies indicate that groundwater was not retained at surface in the conglomeratic member, but sank to a deep water table. Absence of roots, drab units and reduction spheres, as well as absence of pedogenic calcrete and plant fragments (Fig. 3), are supporting evidence of the lack of a continuous supply of surface water on the gravelly porous surface of the upper fan. Abundance of stream flow conglomerate in the conglomerate member suggests that this dryness was seasonal. Emergence of the water table in the transitional facies (interpreted as mid-fan) and below, is suggested by evidence of vegetation and by common drab lithologies, interpreted to indicate swampy and lacustrine environments.

Gypsum is common in soils of arid and semiarid climates (Retallack, 1990). Cementation of fan gravels in Oman by calcrete and gypsum was related by Abrams and Chadwick (1994) to semiarid-arid climate, though they speculated that one similarly cemented gravel was formed under a semiaridhumid climate. Absence of evidence of gypsum, or of its prior existence, in the calcite that cements the conglomerate of the New Glasgow formation suggests that the Westphalian A climate was wetter than arid or semiarid.

The fine-grained member of the New Glasgow fan could be a distal fan facies or an alluvial plain facies, not part of the fan. Most commonly alluvial fans grade distally into alluvial plain deposits, deposited by rivers flowing along tectonic grain, at right angles to the fan axis (Nilsen, 1982; Miall, 1996). Occurrence of distal thinning of the fine-grained member and similarity of paleocurrent direction of the conglomerate and fine-grained members (Fig. 4a,b) suggest that the latter is a distal fan deposit. This conclusion is supported by the presence of the transitional facies and the interdigitated nature (Yeo, 1987; Chandler et al., 1998) of the boundary between the members. Distal deposits of Stephanian alluvial fans in Spain, probably deposited under a seasonal tropical climate, contain flat-bedded and rippled sandstone units interbedded with siltstones and mudstones that include carbonaceous mudstones and coals with underlying rootlet beds. Associated are abundant upright tree trunks and well-preserved plant remains. These facies were interpreted by Heward (1978) as deposited by periodic sheetflood deposition, separated by intervals of plant colonization. Some sandstone bodies in the fine-grained member of the New Glasgow formation are lenticular and cross-bedded. These are interpreted as deposited by waning, confined (within channel) stream flow. Other sandstones in the fine-grained member are flat-bedded and interbedded with drab units, soils, abundant plant remains and evidence of tree growth. This association is similar to that of the distal facies of the Spanish alluvial fans.

Pedogenic calcrete is a prominent feature of the soils of landscapes where seasonal moisture deficit allows $\mathrm{CaCO}_{3}$ to accumulate. It occurs typically in gypsiferous soils such as aridisols which form in arid to semiarid climates, and mollisols which form on Tertiary and later grasslands in subhumid to semiarid climates. It also occurs in vertisols which form in a subhumid to semiarid climate with a pronounced dry season. Vertisols are distinguished from the first two types by vertic structures (Retallack, 1990; Wright and Tucker, 1991; Retallack, 1997). Association of the nodular calcrete with rooted soil profiles suggests that it is pedogenic and formed by evapotranspiration. McFadden and Tinsley (1985) modelled depth of pedogenic calcrete formation in the soil profile as $0 \mathrm{~cm}$ for an arid climate, $20 \mathrm{~cm}$ for a semiarid climate, and $260 \mathrm{~cm}$ for a Mediterranean (southern Californian) climate. The depth of calcrete nodules, measured in one exposure of the fine-grained member of the New Glasgow formation, was $1 \mathrm{~m}$ below the soil top, indicating for this horizon a climate intermediate between semiarid and Mediterranean, an annual rainfall of about 750 mm a year (Retallack, 1997). Calcrete nodules are absent in the upper $28 \mathrm{~cm}$ of another profile (Fig. 9c), indicating at least $200 \mathrm{~mm}$ of annual rainfall (Retallack, 1997). Absence of a grey soil top suggests that the upper part of the soil is missing and that this rainfall estimate may be low.

As noted above, the depositional processes of arid and humid zone fans may be similar in many cases. Appreciable differences are found only in pedogenesis and the lapse in time between major depositional events (Calder, 1991). Rooted soil profiles, absent in the conglomerate member, are numerous in the transitional facies and fine-grained member of the New Glasgow formation. Grey units, also absent in the oxidised conglomerate member, become increasingly abundant downward through these two units. These features indicate shallow water tables in more distal parts of the New Glasgow fan. Several grey, laminated to very thin bedded, graded units, with associated roots and plant fragments occur in the finegrained member. These are interpreted as lacustrine deposits that may have formed by groundwater discharge on the lower fan, a process described by Galloway and Hobday (1983). In summary, the distribution of red and drab units, calcite cement, calcrete nodules, soils, and vegetation in the New Glasgow formation points to infiltration stream water in the upper part of the fan and its discharge in the lower part of the fan.

Zones of slickensides are common in the New Glasgow formation in drill core P-58-86. Slickensides may form due to faulting or compaction and are also a common feature of vertisols (Dudal and Eswaran, 1988). Those formed in faults are near coplanar and concentrated in narrow bands (Retallack, 1990), in many cases at a high angle to bedding. Those formed in soils by seasonal wetting and drying or by their compaction are arranged in diffuse bands coplanar with the host soil (Retallack, 1990). The slickensides in the New Glasgow formation occur in diffuse bands of concave upward, spoon shaped, slip surfaces, with striations commonly oriented along the axis of the spoons. These features, the horizontal to intermediate dip of the surfaces relative to bedding (Wilding and Tessier, 1990), and the association with pedogenic features such as calcrete nodules and roots, especially obliteration of the upper rooted zone of soils (Fig. 9) indicate a pedogenic origin for the slickensides (Gray and Nickelsen, 1989). Although large-scale features of vertisols such as gilgai and vertical cracks (Wilding and Puentes, 1988) are not easily seen 
in drill core P-58-86, the observed features such as slickensides and associated nodular calcrete are evidence that these partial and complete soils are vertisols. These soils are characteristic of subhumid to semiarid tropical climates (180-1520 $\mathrm{mm} / \mathrm{yr}$ precipitation) with a pronounced dry season (Retallack, 1990).

Witzke, (1990) and Francis (1994) proposed that the late Carboniferous Euramerican coal province, of which Nova Scotia is a part, formed in the equatorial humid climate belt. Some writers believed that this everwet climate is necessary for the preservation of coal swamps (Ziegler et al., 1981; Lottes and Ziegler, 1994). In contrast, McCabe (1984), Ziegler et al. (1987) and Parrish (1993) cautioned that waterlogged conditions could be maintained merely by high groundwater tables, and Calder and Gibling (1994) inferred the climate of tropical Euramerica during the Namurian and Westphalian to have been generally humid, ranging from everwet to seasonally wet, with rainfall influenced by orographic rain shadows.

In northern Nova Scotia, and as noted above more generally for the Euramerican coal province, fluvial formations became increasingly redder up through the Westphalian and Stephanian (Ryan and Boehner, 1994). This fits with paleopedological evidence for tropical climates with pronounced dry seasons in the Westphalian C to Stephanian rocks of mainland Nova Scotia (Chandler, 1995, 1997a,b). It is, therefore, likely that coals of this age (Fig. 1), in the adjacent Stellarton coal basin were formed under a seasonal climate and that the peat swamps were, in part at least, groundwater nourished (rheotrophic) rather than rain fed (ombrotrophic). The Westphalian $C$ Waddens Cove Formation directly underlies the Westphalian C-Stephanian coal measures of Cape Breton Island (Boehner and Giles, 1986). Of interest is that Gibling and Rust (1992) cited the near-equatorial latitude of Nova Scotia and the presence of calcrete-free vertisols and ganisters in the Waddens Cove Formation as evidence of a Westphalian C seasonal, humid, tropical climate.

Evidence that the Westphalian A-B coals of the Cumberland Basin were not deposited under an everwet climate comes from a number of sources. Calder $(1991,1994)$ cited the rheomesotrophic nature of a coal seam, red and mottled coeval strata, evidence in fluvial channel sands of strongly fluctuating flow, mire flora (Lepidodendron and Paralycopodites) and ephemeral sheet flood deposits in distal alluvial fan deposits, as evidence of an inequable "perhaps seasonal" climate. In certain coal beds abundant siliciclastic partings are direct evidence of groundwater discharge (Calder and Gibling, 1994) from the correlative to subjacent Polly Brook alluvial fan (Calder, 1994). Further evidence that the Westphalian A-B climate of Nova Scotia may not have been everwet comes from geochemical data suggesting a rheotrophic origin for coals in the late Westphalian A Joggins Formation (Brand, 1994). Rare nodular calcrete in the distal facies of the correlative Polly Brook Formation (Calder, 1985, 1991) is further evidence of dryness. Fusain (fossil charcoal), indicative of periodic dryness (Chaloner and Cope, 1982), common in all sedimentary facies in the late Westphalian A Joggins Formation (Fig. 1a) (Arens, 1991), was interpreted by Calder and Gibling (1994) as due to short term climatic excursions but could also form under a seasonally dry climate.

Paleosol data that relate to the Westphalian A and B climate of Nova Scotia have not yet been documented in detail. Evidence presented here indicates that Westphalian A, and possibly Westphalian B, climate in Nova Scotia was likely tropical and seasonal, with pronounced dry seasons. Also, seasonality during deposition of redbeds in the lower part of the Joggins Formation (Ryan et al., 1990c; Naylor et al., 1992) is suggested by the writer's observations in the formation of scattered soil profiles with green diffuse tops 3 to $5 \mathrm{~cm}$ thick, underlain by mottled mudstone, with vertical root traces, some containing calcrete nodules and abundant slickensides, the last indicative of vertisol development. It also suggests the monsoonal climate related to the assembly of Pangea was already affecting the region by Westphalian A time.

Supporting evidence of earlier Carboniferous seasonality includes reports of vertisols in the late Namurian-early Westphalian Boss Point Formation (Browne, 1990), and by the writer in the early Namurian Hastings Formation in Cape Breton Island (Chandler, 1994, 1995). The writer has also noted vertisols with intersecting low angle, upward-concave slickensides in both the Boss Point Formation and in the older Cheverie Formation of the Tournaisian Horton Group of Nova Scotia. It is likely that more evidence of seasonality will be found from lower Carboniferous rocks of the Canadian Maritime Provinces, for Visean calcrete-bearing vertisols have been reported from Tennessee (Caudill et al., 1996), Vinginia (Stefaniak et al., 1993) and from the United Kingdom (Wright, 1982; Vanstone, 1991). Thus it is very probable that a regional monsoonal climate was affecting the Nova Scotia area early in the Carboniferous.

\section{ECONOMIC IMPLICATIONS}

This paper argues that during formation of early Westphalian, as well as late Westphalian, coal swamps in Nova Scotia, the climate was tropical and seasonal, with a pronounced dry season. Calder (1994) suggested that groundwater discharge from the Polly Brook Formation was important in nourishing the basin margin coal swamps of the Joggins and Springhill formations. This idea implies that drab fluvial-palustrine units associated with Westphalian alluvial fans in the Canadian Maritime Provinces are a likely site for coal deposits.

Data presented above indicate that groundwater was discharged from the lower parts of the New Glasgow fan, supporting the model of Calder (1994).

On Big Island, near the base of the Malagash Formation, which directly overlies the New Glasgow formation, a $30-\mathrm{cm}$ thick coal seam overlies $8 \mathrm{~m}$ of dark grey shale. West of Merigomish Harbour (Fig. 2), stromatolitic carbonate and sandstone of the Smalls Brook Limestone, associated with oil shale and coal at the base of the Malagash Formation (Yeo, 1987; Palmer, 1991), may be evidence of the encroachment of lacustrine conditions over the fan. However, no palynological ages younger 
than early Westphalian A have been recovered from the New Glasgow formation, although the red conglomerate at the top of the New Glasgow formation is undated. Also, the base of the Malagash Formation is of Westphalian C age; therefore, there may be a significant hiatus (Fig. 1), equivalent to the Westphalian B interval between the New Glasgow and Malagash formations. Existence of such a gap is suspected because of the absence of Westphalian $B$ ages from the Stellarton Formation immediately to the south (Waldron et al., 1997; Chandler et al., 1998) and because of the midNamurian to late Westphalian hiatus in the Sydney Coal Basin succession, $200 \mathrm{~km}$ to the northeast (Gibling et al., 1987).

These arguments lead to the suggestion that drab Westphalian A and B coal-bearing units, like the Joggins and Springhill Mines formations of the Cumberland Basin, are missing from the Westphalian succession associated with the New Glasgow formation. It is possible, however, that the upper part of the Boss Point Formation is correlative with the lower part of the New Glasgow formation and may be locally a potential site for coal formation. Also, even if the New Glasgow formation is entirely of Westphalian A age, in the absence of intervening units, this highly permeable unit could have supplied groundwater to nourish coal swamps at the base of the Westphalian C Malagash Formation.

More interestingly, spore dating suggested to Hacquebard (1986) that a $46000 \mathrm{~km}^{2}$ Westphalian C-D coal field may lie beneath the Gulf of St. Lawrence (Fig. 1). From seismic reflection data, Grant (1994) proposed that this basin is part of a larger $90000 \mathrm{~km}^{2}$ basin extending farther south beneath the Northumberland Strait to the north shore of Nova Scotia and that some of the lower coal measures interpreted from seismic reflectors in the basin might be correlative with the Westphalian A-B coals of the Cumberland Basin. This last suggestion is supported by the above proposition that coal swamps ought to have formed to the north of the Westphalian A-B? New Glasgow fan.

Recognition of a Westphalian A monsoonal climate with marked dry seasons for Nova Scotia has implications also for genetic modelling of sandstone-hosted lead deposits, an example of which is the Yava deposit of Cape Breton Island (Fig. 1). At Yava, galena formed diagenetic pore fillings in sandstone at the base of the grey, fluvial Silver Mine Formation, where it overlies the lead-rich, Devonian, Salmon River Porphyry (Sangster and Vaillancourt, 1990). The host Silver Mine Formation contains coal seams, indicative of swampy conditions (Boehner and Prime, 1993) as well as histosols, a soil type indicative of permanent waterlogging (Retallack, 1990). S. Barss (written communication to Boehner and Prime, 1993) identified the Silver Mine Formation as late Namurian to early Westphalian $A$ in age. Five spore samples from the upper member of the formation range in age from late early Westphalian A to latest Westphalian A, equivalent in spore zonation to the Joggins Formation (Fig. 1).

From their review of sandstone-hosted lead deposits, Bjorlykke and Sangster (1981) cited association of evaporites with some deposits to indicate formation under a warm and semiarid climate. On the other hand, lack of carbonates with some marine deposits suggests a cooler climate. Presence of abundant plant material with some late Phanerozoic deposits suggests a more humid climate. They concluded that these deposits formed under a range of climates, with the majority favouring a warm semiarid climate. Noting paucity of associated redbeds, they favoured thorough weathering of a leadrich granitic basement under stable tectonic conditions and a humid paleoclimate to furnish the lead for the Carboniferous Yava deposit of Nova Scotia. Bonham (1983) also favoured deposition of the Silver Mine Formation under a humid climate and Boehner and Prime (1983) invoked a "moderate" climate to permit development of peat mires in the Silver Mine Formation.

As shown above, Westphalian A-B coal swamps developed in the Joggins-Springhill area of Nova Scotia in the face of a seasonal tropical climate with a pronounced dry season. The Silver Mine Formation, the coal swamp-bearing host rock of the Yava deposit, a stratigraphic equivalent of the Cumberland Basin coal swamps, probably formed under similar climatic conditions.

\section{Conclusions}

(1) The proximal conglomeratic member and the distal finegrained member of the New Glasgow formation formed in an alluvial fan. They contain climate-sensitive features indicating deposition in a tropical seasonal climate with a marked dry season.

(2) Paleopedological, groundwater, and other sedimentological data from the New Glasgow fan provide evidence to support the suggestion of Calder (1994) that Westphalian AB coal swamps of the Cumberland Basin were nourished during the dry season by groundwater emerging from the toe of alluvial fans. In consequence, paludal units correlative with other Carboniferous alluvial fans of the Maritime Provinces should be re-examined as potential sources of coal.

(3) Paleoclimate data from the Westphalian A Silver Mine Formation, host to the Yava sandstone-hosted lead deposit in Cape Breton Island, Nova Scotia, show that such deposits can form in fluvial host rocks deposited under swampy conditions under a tropical seasonal climate with a pronounced dry season.

\section{ACKNOWLedgements}

I wish to thank John Calder and Bob Ryan of the Nova Scotia Department of Mines and Energy, Peter Giles and Al Grant of the Geological Survey of Canada, and John Waldron of St. Mary's University for enlightening discussions. Rob Naylor of the Nova Scotia Department of Mines and Energy and Clint St. Peter of the New Brunswick Department of Natural Resources and Energy provided painstaking and very valuable reviews. Sandra Barr of Acadia University suggested many improvements in the style of the manuscript. The staff of the Stellarton core library of the Nova Scotia Department of Mines and Energy have been unstinting in their logistical support. This study was supported by the Federal Government-Nova Scotia Government Mineral Development Agreement 19941997. 
Abrams, M.J. and Chadwick, O.H. 1994. Tectonic and climatic implications of alluvial fan sequences along the Batinah coast, Oman. Journal of the Geological Society, London, 151, pp. 51-58.

Arens, N. 1991. Vegetation replacement following wildfire disturbance in middle Pennsylvanian clastic wetlands: Examples from Joggins, Nova Scotia, Canada. Geological Society of America, Abstracts with Programs, 23, p. 456.

Bell, W.A. 1925. The New Glasgow Conglomerate member of Pictou County, Nova Scotia. Canadian Institute of Mining and Metallurgy, Transactions, 28, pp. 447-476.

----- 1926. Carboniferous formations of Northumberland Strait, Nova Scotia. Geological Survey of Canada, Summary Report 1924, Pt. C, pp. 142-180.

Bell, R. 1940. The Pictou Coalfield, Nova Scotia. Geological Survey, Department of Mines and Resources, Ottawa, Memoir 225, $161 \mathrm{p}$.

Bjorlykke, A. and Sangster, D.F. 1981. An overview of sandstone lead deposits and their relation to redbed copper and carbonate hosted lead-zinc deposits. 75th Anniversary Volume of Economic Geology, 1981, pp. 179-213.

Boehner, R.C. and GILES, P.S. 1986. Geological map of the Sydney Basin, Nova Scotia. Nova Scotia Department of Mines and Energy, Map 86-1, scale 1:50 000 .

Boenner, R. and Prime, G. 1993. Geology of the Loch Lomond Basin and Glengarry Half Graben, Richmond and Cape Breton Counties, Cape Breton Island, Nova Scotia. Mines and Energy Branches, Nova Scotia Department of Natural Resources, Memoir 9, 68 p.

Bonham, O.J.H. 1983. Mineralization controls at the Yava lead deposit, Salmon River, Cape Breton County, Nova Scotia. Unpublished M.Sc. thesis, Dalhousie University, Halifax, Nova Scotia, 251 p.

BRAND, U. 1994. Continental hydrology and climatology of the Carboniferous Joggins Formation (lower Cumberland Group) at Joggins, Nova Scotia: evidence from geochemistry of bivalves. Palaeogeography, Palaeoclimatology, Palaeoecology, 106, pp. 307-321.

Brierley, G.J., Llu, K., and CRook, K.A.W. 1993. Sedimentology of coarse-grained alluvial fans in the Markham Valley, Papua New Guinea. Sedimentary Geology, 86, pp. 297-324.

Browne, G.H. 1990. The sedimentology of the Boss Point Formation (Pennsylvanian), eastern New Brunswick and northern Nova Scotia. Unpublished Ph.D. thesis, University of Western Ontario, $552 \mathrm{p}$.

CALDER, J.H. 1985. Depositional environment of the Westphalian B, Cumberland Basin coals of Springhill, Nova Scotia. In Mines and Minerals Branch, Report of Activities 1984. Edited by K.A. Mills and J.L. Bates. Nova Scotia Department of Mines and Energy, Report 85-1, pp. 11-12.

- 1991. Controls and Westphalian peat accumulation: the Springhill Coalfield, Nova Scotia. Ph.D. thesis (unpublished), Dalhousie University, Halifax, Nova Scotia, 310 p.

----- 1994. The impact of climate change, tectonism and hydrology on the formation of Carboniferous tropical intermontane mires: the Springhill coalfield, Cumberland Basin, Nova Scotia. Palaeogeography, Palaeoclimatology, Palaeoecology, 106, pp. 323-351.

Calder, J.H. and Giblng, M.R. 1994. The Euramerican Coal Province: controls on Late Paleozoic peat accumulation. Palaeogeography, Palaeoclimatology, Palaeoecology, 106, pp. 1-21.

Caudill, M.R., Driese, S.G., and Mora, C.I. 1996. Preservation of a paleo-vertisol and an estimate of late Mississippian paleoprecipitation. Journal of Sedimentary Research, 66, pp. 58-70.
Cecil, C.B. 1990. Paleoclimate controls on stratigraphic repetition of chemical and siliciclastic rocks. Geology, 18, pp. 533-536.

Cecil, C.B., Stanton, R.W., Neuzil, S.G., Dulong, F.T., Ruppert, L.F., and Pierce, B.S. 1985. Paleoclimate controls on Late Paleozoic sedimentation and peat formation in the central Appalachian Basin. International Journal of Coal Geology, 5, pp. 195-230.

Cecil, C.B., Dulong, F.T., Edgar, N.T., and Ahlbrandt, T.S. 1994. Carboniferous Paleoclimates, Sedimentation and Stratigraphy. In Predictive Stratigraphic Analysis - Concept and Application. Edited by C.B. Cecil and N.T. Edgar. United States Geological Survey, Bulletin 2110, pp. 27-28.

Chaloner, W.G. and Cope, M.J. 1982. Interaction of Plant Evolution, Wildfire, Atmospheric Composition and Climate. Proceedings, Third North American Paleontological Convention, 1, pp. 83-85.

Chandler, F.W. 1994. Highlights of Geological Mapping in the Stellarton Gap (NTS 11E/7,9,10,15), with Comments on Carboniferous Paleoclimate and its Economic Significance. In Program and Summaries, Eighteenth Annual Review of Activities, Nova Scotia Department of Natural Resources, Mines and Energy Branch, Report 94-2, p. 37.

----- 1995. Geological mapping in the Stellarton Gap (NTS 11E/ $7,9,10,15)$, a status report. Atlantic Geoscience Society, Colloquium and Annual general Meeting, St. Francis Xavier University, Antigonish, Nova Scotia, Program and Abstracts, 1995, pp. 9-10.

1997a. The Canfield Creek copper deposit, Nova Scotia a late Carboniferous cupriferous bog deposit: implications for exploration for redbed copper in Carboniferous clastics in Nova Scotia and New Brunswick. In Current Research, 1997D, Geological Survey of Canada, pp. 35-42.

-..- 1997b. Tectonics, paleoclimate and sandstone-hosted base metal deposits: cause and effect in the Carboniferous Maritimes Basin, eastern Canada. Abstract Volume, Geological Association of Canada/Mineralogical Association of Canada, Annual Meeting, Ottawa 1997, p. A24.

Chandler, F.W., Waldron, J.W.F., Giles, P., and Gall, Q. 1998. Geology of the Stellarton Gap, Nova Scotia, NTS 11E/10 and parts of NTS 11E/7,9,15. Geological Survey of Canada, Open File Map 3535, 1:50 000 scale.

Crowley, T.J., Hyde, W.T., and Short, D.A. 1989. Seasonal cycle variations on the supercontinent of Pangea. Geology, 17, pp. 457-460.

Dawson, J. 1845. On the Newer Coal Formation of the Eastern Part of Nova Scotia. Quarterly Journal of the Geological Society of London, 1, pp. 322-330.

DoLbY, G. 1987. Palynology analysis of samples from the Cumberland Basin and Cape Breton Island, Nova Scotia. Project 86/10,12. Unpublished report, prepared for Mineral Resources Division, Cumberland Basin Project; Nova Scotia Department of Mines and Energy, Open File Report 87-033, 58 p. 1988. Palynological analysis (of) samples from the Cumberland Basin and Cape Breton Island, Nova Scotia. Part II. Unpublished report prepared for the Nova Scotia Department of Mines and Energy, 34 p.

Donaldson, A.C., Renton, J.J., and Prestey, M.W. 1985. Pennsylvanian Deposystems and Paleoclimates of the Appalachians. International Journal of Coal Geology, 5, pp. 167-193.

Dudal, R. and Eswaran, H. 1988. Distribution, properties and classification of vertisols. In Vertisols: Their Distribution, Properties, Classification and Management. Edited by L.P. Wilding and R. Puentes. Technical Monograph, No. 18, Soil 
Management Support Services (1988), Texas A\&M University, pp. 1-22.

EbLe, C.F. 1985. Applications of Coal Palynology To Biostratigraphic and Paleoecologic Analyses of Pennsylvanian Coal Beds. In Predictive Stratigraphic Analysis - Concept and Application. Edited by C.B. Cecil and N.T. Edgar. United States Geological Survey, Bulletin 2110, pp. 28-32.

Fastovsky, D.E., Driese, S.G., Strater, K.P., and Strater, N.H. 1993. Paleosols in Mauch Chunk Formation (Upper Mississippian) Near Lavenne, PA. Day 2, Stop 4. In Paleosols, Paleoclimate and Paleoatmospheric $\mathrm{CO}_{2}$; Paleozoic Paleosols of Central Pennsylvania. Edited by S.G. Driese. University of Tennessee, Department of Geological Sciences, Studies in Geology, 22, pp. 80-90.

FLORES, R.M. 1986. Styles of coal deposition in Tertiary alluvial deposits, Powder River Basin, Montana and Wyoming. In Paleoenvironmental and tectonic controls in coal-forming basins of the United States. Edited by P.C. Lyons and C.L. Rice. Geological Society of America, Special Paper 210, pp. 79-104.

Fralick, P.W. and Schenk, P.E. 1981. Molasse deposition and basin evolution in a wrench tectonic setting: the late Paleozoic, eastern Cumberland Basin, Maritime Canada. In Sedimentation and Tectonics in Alluvial Basins. Edited by A. Miall. Geological Association of Canada, Special Paper 23, pp. 77-97.

Francis, J.E. 1994. Paleoclimates of Pangea - geological evidence. In Pangea: Global environments and resources. $E d$ ited by A.F. Embry, B. Beauchamp and D.J Glass. Canadian Society of Petroleum Geologists, Memoir 17, pp. 295310.

Funk, J.M. 1979. Distribution of Carbonate Cements in Quaternary Alluvial-Fan Deposits, Birch Creek Valley, East-Central Idaho-Diagenetic Model. American Association of Petroleum Geologists, Bulletin 63, p. 454.

Galloway, W.E. and Hobday, D.K. 1983. Terrigenous Clastic Depositional Systems, Application to Petroleum, Coal, and Uranium Exploration. Springer, New York, 423 p.

Garces, B.L., Gierlowski-Kordesch, E., and Bragonier, W.A. 1996. Pennsylvanian continental cyclothem development: no evidence of direct climatic control in the Upper Freeport Formation (Alleghenny Group) of Pennsylvania (northern Appalachian Basin). Sedimentary Geology, 109, pp. 305-319.

Gibling, M.R. and BIRD, D. 1994. Late Carboniferous cyclothems and alluvial paleovalleys in the Sydney Basin, Nova Scotia. Geological Society of America, Bulletin 106, pp. 105-117.

Gibling, M.R. and Rust, B.R. 1992. Silica-cemented paleosols (ganisters) in the Pennsylvanian Waddens Cove Formation, Nova Scotia, Canada. In Diagenesis III, Developments in Sedimentology, 47, pp. 621-655.

Gibling, M.R. and Wightman, W.G. 1994. Paleovalleys and protozoan assemblages in a Late Carboniferous cyclothem, Sydney Basin, Nova Scotia. Sedimentology, 41, pp. 699-719.

Gibling, M.R., Boehner, R.C., and Rust, B.R. 1987. The Sydney Basin of Atlantic Canada: an Upper Paleozoic strike-slip basin in a collisional setting. Canadian Society of Petroleum Geologists, Memoir 12, pp. 269-285.

Gibling, M.R., Calder, J.H., and Naylor, R.D. 1992a. Carboniferous coal basins of Nova Scotia. Geological Association of Canada, Mineralogical Association of Canada, Joint Annual Meeting, Wolfville '92, Field Trip C-1, Guidebook, 84 p.

Gibling, M.R., Calder, J.H., Ryan, R., Van De Poll, H.W., and YEO, G. 1992b. Late Carboniferous and Early Permian drainage patterns in Atlantic Canada. Canadian Journal of Earth Sciences, 29 , pp. 338-352.
Gibling, M.R., Tandon, S.K., and Wightman, W.G. 1993. Calcareous Palaeosols as indicators of climato-eustatic change in Late Carboniferous cyclothems of Sydney Basin, Nova Scotia. Abstracts with Programs, Geological Society of America, Annual Meeting, 25, p. 399.

Gillis, J.W. 1964. Geology of northwestern Pictou County, Nova Scotia. Unpublished Ph.D. thesis and map, Pennsylvania State University, University Park, Pennsylvania, 130 p.

Grant, A.C. 1994. Aspects of seismic character and extent of Upper Carboniferous Coal Measures, Gulf of St. Lawrence and Sidney Basin. Palaeogeography, Palaeoclimatology, Palaeoecology, 106, pp. 271-285.

GraY, M.B. and Nickelsen, R.P. 1989. Pedogenic slickensides, indicators of strain and deformation processes in redbed sequences of the Appalachian foreland. Geology, 17, pp. 72-75.

HacQuebard, P.A. 1986. The Gulf of St. Lawrence Carboniferous Basin; the largest coalfield in eastern Canada. Canadian Institute of Mining and Metallurgy, Bulletin 79, No. 891, pp. 67-78.

Heward, A.P. 1978. Alluvial fan and lacustrine sediments from the Stephanian A and B (La Magdalena, Cinera-Matallana and Sabero) coalfields, northern Spain. Sedimentology, 25, pp. $451-488$.

Hunt, C.B. 1975. Death Valley. Geology, Ecology, Archaeology. University of California Press, 234 p.

JoHnson, S.C. 1995. Stratigraphy of Upper Carboniferous strata, southeastern New Brunswick. Abstracts, Twentieth Annual Review of Activities, New Brunswick Department of Natural Resources and Energy, Minerals and Energy, Miscellaneous Report 20, p. 7.

Kalliokoski, J. 1986. Calcium carbonate cement (caliche) I Keweenawan sedimentary rocks $(-1.1 \mathrm{Ga})$, upper peninsula of Michigan. Precambrian Research, 32, pp. 243-259.

Kochel, R.C. 1990. Humid Fans of the Appalachian Mountains. In Alluvial Fans: A Field Approach. Edited by A.H. Rachocki and M. Church. Wiley, Chichester, pp. 109-129.

Kutzbach, J.E. and Gallimore, R.G. 1989. Pangean climates, Megamonsoons of the Megacontinent. Journal of Geophysical Research, 94, No. 3D, pp. 3341-3357.

Lattman, L.H. 1973. Calcium Carbonate Cementation of Alluvial Fans in Southern Nevada. Geological Society of America, Bulletin, 84, pp. 3013-3028.

LotTes, A.L. and Ziegler, A.M. 1994. World peat occurrence and the seasonality of climate and vegetation. Palaeogeography, Palaeoclimatology, Palaeoecology, 106, pp. 23-37.

MachetTe, M.N. 1985. Calcic soils of the southwestern United States. In Soils and Quaternary Geology of the southwestern United States. Edited by D.L. Weide. Geological Society of America, Special Paper 203, pp. 1-21.

Maizels, J. 1989. Sedimentology, paleoflow dynamics and flood history of jokulhlaup deposits; paleohydrology of Holocene sediment sequences in southern Iceland sandur deposits. Joumal of Sedimentary Petrology, 59, pp. 204-223.

Major, J.J. 1997. Depositional Processes in Large-Scale DebrisFlow Experiments. Journal of Geology, 105, pp. 345-366.

McCABE, P.J. 1984. Depositional environments of coal and coalbearing strata. In Sedimentology of coal and coal-bearing sequences. Edited by R.A. Rahmani and R.M. Flores. International Association of Sedimentologists, Special Publication No. 7, pp. 13-42.

McCABE, P.J. and Schenk, P.E. 1982. From Sabkha to coal swamp - the Carboniferous sediments of Nova Scotia and southern New Brunswick. International Association of Sedimentologists, 11 th International Congress on Sedimentology, Hamilton, Canada, Excursion Guidebook 4a, 169 p. 
McFAdDen, L.D. and Tinsley, J. 1985. Rate and depth of pedogeniccarbonate accumulation in soils: formulation and testing of a comparative model. In Soils and Quaternary geology of the Southwestern United States. Edited by D.L. Weide and M.L. Faber. Geological Society of America, Special Paper 203, pp. 23-42.

McGowen, J.H. 1979. Alluvial Fan Systems, Chapter 4. In Depositional and Ground-Water Flow Systems in the Exploration for Uranium. Edited by W.E. Galloway, C.W. Kreitler, and J.H. McGowen. Bureau of Economic Geology, University of Texas, Austin, pp. 43-79.

Miall, A.D. 1978. Lithofacies types and vertical profile models in braided river deposits, a summary. In Fluvial Sedimentology. Edited by A.D. Miall. Canadian Society of Petroleum Geologists, Memoir 5, pp. 597-604.

-.--- 1992. Alluvial deposits. In Facies Models: response to sea level change. Edited by R.G. Walker and N.P. James. Geological Association of Canada, St. John's, Newfoundland, pp. 119-142.

Miall, A.D. 1996. The Geology of Fluvial Deposits, Sedimentary Facies, Basin Analysis and Petroleum Geology. Springer, Berlin, 582 p.

NaYlor, R.D., Kalkreuth, W.D., Smith, W.D., and Yeo, G.M. 1989. Stratigraphy, sedimentology and depositional environments of the coal-bearing Stellarton Formation, Nova Scotia. Geological Survey Canada, Paper 89-8, pp. 2-13.

Naylor, R.D., Calder, J.H., Ryan, R.J., and Martel, T.A. 1992. Controls on formation of upper Carboniferous coals in the intermontane Stellarton and Cumberland Basins of Atlantic Canada. In Proceedings of the Canadian Coal and Coalbed Methane Geoscience Forum Parksville, British Columbia, pp. 365-397.

Nemec, W. and Steel, R.J. 1984. Alluvial and coastal conglomerates: their significant features and some comments on gravelly mass flow deposits. In Sedimentology of Gravels and Conglomerates. Edited by E.H. Koster and R.J. Steel. Canadian Society of Petroleum Geologists, Memoir 10, pp. 1-31.

NiLsen, T.H. 1982. Alluvial Fan Deposits. In Sandstone Depositional Environments. Edited by P.A. Scholle and D. Spearing. American Association of Petroleum Geologists, Memoir 31, pp. 4986.

Ollier, C. and Pain, C. 1996. Regolith, Soils and Landforms. Wiley, Chichester, $316 \mathrm{p}$.

ONo, Y. 1990. Alluvial fans in Japan and South Korea. In Alluvial Fans: a field approach. Edited by A.H. Rochicki and M. Church. Wiley, Chichester, pp. 91-107.

Orton, G.J. 1988. A spectrum of Middle Ordovician fan deltas and braidplain deltas, North Wales: a consequence of varying clastic input. In Fan deltas: sedimentology and tectonic setting. Edited by W. Nemec and R.J. Steel. Blackie, Glasgow, pp. 23-49.

Otto-Bliesner, B.L. 1993. Tropical mountains and coal formation; a climate model of the Westphalian (306 Ma). Geophysical Research Letters, 20, 18, pp. 1947-1950.

PALMER, S.E. 1991. Carbonates and associated sediments in the Merigomish Formation of the Stellarton Gap, Nova Scotia. B.Sc. thesis (unpublished), St. Mary's University, 64 p.

Parrish, J.T. 1993. Climate of the Supercontinent Pangea. Journal of Geology, 101, pp. 215-233.

Phillips, T.L. and Peppers, R.A. 1984. Changing patterns of Pennsylvanian coal-swamp vegetation and implications of climatic control on coal occurrence. International Journal of Coal Geology, 3, pp. 205-255.

Pierson, T.C. 1980. Erosion and deposition by debris flows at Mt. Thomas, New Zealand. Earth Surface Processes, pp. 1952-1984.
Reading, H.G. 1996. Sedimentary Environments: Process, Facies and Stratigraphy, Third Edition. Blackwell Science, Oxford, $688 \mathrm{p}$.

Retallack, G.J. 1990. Soils of the Past, an introduction to paleopedology. Unwin Hyman, Boston, 520 p.

-..-- 1997. A colour guide to paleosols. Wiley, Chichester, 175 p.

Robinson, P.L. 1973. Paleoclimatology and continental drift. In Implications of Continental Drift to the earth Sciences, 1. Edited by D.H. Tarling and S.K. Runcorn. Academic Press, London, pp. $451-476$.

Rowley, D.B., Raymond, A., Totman Parrish, J., Lottes, A.L., Scotese, C.R., and ZigGler, A.M. 1985. Carboniferous paleogeographic, phytogeographic and paleoclimatic reconstructions. International Journal of Coal Geology, 5, pp. 742.

Ryan, R.J. and Boenner, R.C. 1990. Tatamagouche and Malagash, Cumberland, Colchester and Pictou Counties. Cumberland Basin Geological Map, 90-14, Nova Scotia Department of Natural Resources, Scale, 1:50 000.

- 1994. Geology of the Cumberland Basin, Cumberland, Colchester and Pictou Counties, Nova Scotia. Nova Scotia Department of Natural Resources, Memoir 10, 222 p.

Ryan, R.J., Boehner, R.C., and Deal, A. 1990a. Cumberland Basin Geology Map, Apple River and Cape Chignecto, NTS 21H/ 7 and 10. Nova Scotia Department of Mines and Energy, Map 90-11, Scale 1:50 000.

-_- 1990b. Cumberland Basin Geology Map, Oxford and Pugwash, Cumberland County. Nova Scotia Department of Mines and Energy, Map 90-13, Scale 1:50 000.

Ryan, R.J., Boehner, R.C., Deal, A., and Calder, J.H. 1990c. Cumberland Basin Geology Map, Amherst, Springhill and Parrsboro, Cumberland County. Nova Scotia Department of Natural Resources, Map 90-12, Scale, 1:50 000.

RYAN, R.J., BOEHNER, R.C., and CALDER, J.H. 1991. Lithostratigraphic Revisions of the Upper Carboniferous to Lower Permian strata in the Cumberland Basin, Nova Scotia and the regional implications for the Maritimes Basin in Atlantic Canada. Bulletin of Canadian Petroleum Geology, 39, pp. 289-314.

Sangster, D.F. and Valllancourt, P.D. 1990. Geology of the Yava sandstone-lead deposit, Cape Breton Island, Nova Scotia, Canada. In Mineral Deposit Studies in Nova Scotia, 1. Edited by A. L. Sangster. Geological Survey of Canada, Paper 90-8, pp. 203-244.

Schenk, P.E., von Bitter, P.H., and Matsumoto, R. 1994. Deep basin/deep water carbonate-evaporite deposition of a saline giant: Loch Macumber (Visean), Atlantic Canada. Carbonates and Evaporites, 9, pp. 187-210.

Scotese, C.R. and McKerrow, W.S. 1990. Revised world maps and introduction. Palaeozoic paleogeography and biogeography. Edited by W.S. McKerrow and C.R. Scotese. Geological Society, Memoir 12, pp. 1-21.

Selley, R.C. 1988. Applied Sedimentology. Academic Press, London, $446 \mathrm{p}$.

Singh, H., Parkash, B., and Gohain, K. 1993. Facies analysis of the Kosi megafan deposits. Sedimentary Geology, 85, pp. 87-113

Stalder, P.J. 1975. Cementation of Pliocene-Quaternary fluviatile clastic deposits in and along the Oman Mountains. Geologie en Mijnbouw, 45, pp. 148-156.

Stanistreet, I.G. and McCArthy, T.S. 1993. The Okavango Fan and the classification of subaerial fan systems. Sedimentary Geology, 85, pp. 115-133.

Stefaniak, A., Mora, C.I., and Driese, S.G. 1993. Pedogenic and groundwater carbonates in vertic paleosols in the Mississippian MacCrady Formation, SE West Virginia. Geologi- 
cal Society of America, Abstracts with Programs, Annual Meeting, 25/6, p. A-399.

Vanstone, S.D. 1991. Early Carboniferous (Mississippian) paleosols from southwest Britain: Influence of climatic change on soil development. Journal of Sedimentary Petrology, 61, pp. 445457.

Waldron, J.W.F., Durling, P.W., Gillis, K.S., and Howells, K. 1997. Namurian to post-Westphalian deformation History along the Cobequid-Hollow Fault System at the south Margin of the Maritimes Basin. Geological Association of Canada - Mineralogical Association of Canada, Joint Annual Meeting, Ottawa, May 1997, Abstract Volume, p. Als6.

WebB, G.W. 1969. Paleozoic Wrench Faults in Canadian Appalachians. In North Atlantic-Geology and Continental Drift. Edited by Marshall Kay. American Association of Petroleum Geologists, Memoir 12, pp. 754-786.

Wescott, W.A. 1990. The Yallahs fan delta: a coastal fan in a humid tropical climate. In Alluvial Fans: A Field Approach. Edited by A.H. Rachocki and M. Church. Wiley, Chichester, pp. 213-225.

Wilding, L.P. and Puentes, R. (editors). 1988. Vertisols: Their Distribution, Properties, Classification and Management. Technical Monograph, No. 18, Soil Management Support Services (1988), Texas A\&M University, 193 p.

Wilding, L.P. and Tessier, D. 1990. Genesis of Vertisols: ShrinkSwell Phenomena. In Vertisols: Their Distribution, Properties, Classification and Management. Edited by L.P. Wilding and R. Puentes. Technical Monograph, No. 18, Soil Management Support Services (1988), Texas A\&M University, pp. 55-81.

Winston, R.B. and Stanton, R.W. 1989. Plants, Coal, and Climate in the Pennsylvanian of the Central Appalachians. In Coal and Hydrocarbon resources of North America, 2, Carboniferous Geology of the Eastern United States. Field trips for the 28th International Geological Congress. Edited by C.C. Blaine and C.F. Eble. American Geophysical Union, Washington, D.C., pp. 118-126.

Witzke, B.J. 1990. Paleoclimatic constraints for Paleozoic Paleolatitudes of Laurentia and Euramerica. In Palaeozoic Paleogeography and Biogeography. Edited by W.S. McKerrow and C.R. Scotese. Geological Society, Memoir No. 12, pp. 57-73.

WRIGHT, V.P. 1982. Calcrete paleosols from the lower Carboniferous Llanelly Formation, South Wales. Sedimentary Geology, 33, pp. 1-33.
----- 1990. Equatorial aridity and climatic oscillations during the early Carboniferous, southern Britain. Joumal of the Geological Society, 147, pp. 359-363.

WRIGHT, V.P. and RoBinson, D. 1988. Early Carboniferous floodplain deposits from South Wales: a case study of the controls on paleosol development. Journal of the Geological Society, London, 145, pp. 847-857.

WRIGHT, V.P. and TUCKER, M.E. 1991. Calcretes: an Introduction. In Calcretes. Reprint series 2. Edited by V.P. Wright and M.E. Tucker. Blackwell, Oxford, International Association of Sedimentologists, $352 \mathrm{p}$.

YEO, G.M. 1985. Upper Carboniferous sedimentation in northern Nova Scotia and the origin of the Stellarton Basin. In Geological Survey of Canada, Paper 85-1B, pp. 511-518. 1987. Geological Map of the New Glasgow - Toney River area (NTS 11E/10 and 11E/15S). Geological Survey of Canada, Open File 1656.

YEo, G.M. and GAO, R. 1986. Late Carboniferous dextral movement on the Cobequid-Hollow Fault system, Nova Scotia: evidence and implications. In Current Research, Part A, Geological Survey of Canada, Paper 86-1A, pp. 399-410.

Yeo, G.M., Kalkreuth, W.D., Dolby, G., and White, J.C. 1988. Preliminary report on petrographic, palynological and geochemical studies of coals from the Pictou Coalfield, Nova Scotia. In Current Research, Part B, Geological Survey of Canada, Paper 88-1B, pp. 29-40.

Ziegler, A.M., Raymond, A.L., Gierlowski, T.C., Horrell, M.A., Rowley, D.B., and LotTes, A.M. 1987. Coal, climate and terrestrial productivity: the present and Early Cretaceous compared. In Coal and coal-bearing strata. Edited by A.C. Scott. Geological Society, London, Special Publication 32, pp. 25-49.

Ziegler, A.M., Bambach, R.K., Parrish, J.T., Barrett, S.F., Gierlowsk, E.H., PARker, W.C., Raymond A., and Sepkoski, J.J., JR. 1981. Paleozoic biogeography and climatology. In Paleobotany, Paleoecology and Evolution, 2. Praeger, New York, pp. 231266.

Ziegler, P.A. 1989. Evolution of Laurussia. A Study in Late Paleozoic Plate Tectonics. Kluwer Academic Publishers, Dordrecht, $102 \mathrm{p}$. 